\title{
Patronos, clientela y patrocinios. La tipología iconográfica de la Virgen de la Misericordia y del patrocinio de san José en la Nueva España
}

\author{
Patrons, clientele and Patronage: Iconography of The Virgin of Mercy \\ and Saint Joseph's Patronage in New Spain
}

Artículo recibido el 9 de octubre de 2020; devuelto para revisión el 9 de enero de 202I; aceptado el I2 de enero de 202I; https://doi.org/IO.2220I/iie.I8703062e.2021.119.2760

Antonio Rubial García Universidad Nacional Autónoma de México, Facultad de Filosofía y Letras,arubial@unam.mx, https://orcid.org/oooo-0002-9370-508X

Líneas de investigación Sociedad y cultura en la Nueva España; historia de la Iglesia y del cristianismo.

Lines of research Culture and society in New Spain; history of catholic church and christianism.

Resumen Una de las representaciones más populares en el arte novohispano fue la que mostraba a la Virgen o a los santos protegiendo bajo su manto a comunidades y autoridades, con base en el esquema clientelar y corporativo propio del Antiguo Régimen. El mayor número de ejemplos de tal modelo iconográfico pertenece al siglo xvin y presenta a las diversas órdenes religiosas y a otras corporaciones como las receptoras principales de los beneficios celestiales. La difusión de dicho modelo fue una de las respuestas que promovieron las organizaciones religiosas para enfrentar las políticas borbónicas que limitaban sus antiguos privilegios. Con estos y otros discursos visuales, frailes y monjas mostraban que su presencia era fundamental para toda sociedad que se llamara católica.

Palabras clave Iconografía de los santos; iconografía del patrocinio; órdenes religiosas y clero secular en la Nueva Espańa.

Abstract One of the most popular representations in Novo-Hispanic art was that which showed the Virgin or the saints protecting communities and authorities under their cloaks, symbolizing the patronage and corporate scheme of the Old Regime. The majority of examples of such an iconographic model belong to the I8th century and present the various 
religious orders and other corporations as the main recipients of heavenly benefits. The dissemination of this model was one of the responses promoted by religious organizations to confront Bourbon policies that limited their former privileges. With these and other visual statements, friars and nuns showed that their presence was essential for any society that called itself Catholic.

Keywords Iconography of the saints; iconography of patronage; religious orders and secular clergy in New Spain. 
DOI: https://doi.org/10.22201/iie.18703062e.2021.119.2760

\author{
ANTONIO RUBIAL GARCÍA
}

FACULTAD DE FILOSOFÍA Y LETRAS, UNAM

\title{
Patronos, clientela y patrocinios. La tipología iconográfica de la Virgen de la Misericordia y del patrocinio de San José en la Nueva España
}

Porque es María Santísima tan soberana princesa que corresponde liberal al menor agasajo con el más crecido beneficio; lábrale casa de oro sus esclavos, sus cofrades, santificada con la presencia de su preciosísimo Hijo: la salvación de esta casa.

Fray Joseph del VALLE

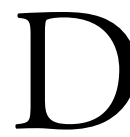

esde el siglo in la Virgen María ha sido objeto de súplicas por parte de los fieles; en una de las primeras oraciones en copto dirigida a ella, y conservada en un papiro de la Biblioteca John Rylands de Mánchester, así se la invoca: "Bajo tu amparo nos acogemos, santa madre de Dios, no deseches las súplicas que te dirigimos en nuestras necesidades, antes bien líbranos de todo peligro ¡Oh siempre Virgen gloriosa y bendita!”2 Aunque dicha

I. Joseph del Valle, Sermón que dijo el día cuarto de la consagración de la capilla del Rosario de Puebla, Octava maravilla, citado en Diego Gorozpe O.P., Octava Maravilla del Nuevo mundo en la gran capilla del Rosario dedicada y aplaudida en el templo de Nuestro Padre Santo Domingo en la Ciudad de los Ángeles, edición facsimilar (Puebla: Junta de Mejoramiento Moral, Cívico y Material del Municipio de Puebla, I985 [I690]), I45.

2. Esta versión está tomada de la traducción latina del siglo XI del texto original en griego, muy cercano a las versiones en copto, armenio y siriaco. Véase Frederica Matthewes-Green. The Lost Gospel of Mary: The Mother of Jesus in Three Ancient Texts (Brewster, MA: Paraclete Press, 2007), 85-87, en https://es.wikipedia.org/wiki/Sub_tuum_praesidium (consultado el 23 de agosto de 202I). 


\section{DOI: https://doi.org/10.22201/iie.18703062e.2021.119.2760}

172

ANTONIO RUBIAL GARCÍA

oración se tradujo a diferentes lenguas y las iglesias cristianas la utilizaron desde el siglo IV, no fue sino hasta el siglo XIII que su amparo se plasmó en un modelo iconográfico que la mostraba protegiendo bajo un gran manto a sus "hijos", quienes arrodillados y con miradas suplicantes esperaban su auxilio. Dicho modelo respondía a una advocación de la Virgen conocida como la Madonna della Misericordia, y una de sus primeras representaciones fue la que realizó Duccio di Buonisegna para los franciscanos en I280. Dicha imagen partió, como lo señala Manuel Trens, de una narración del cisterciense Cesario de Heisterback sobre una visión que tuvo un monje de su orden en la cual la "Reina del Cielo", para mostrarle el amor que tenía a su orden, abrió el manto que la cubría, "que era de una anchura prodigiosa", y le mostró que bajo él había una multitud "de monjes, conversos y monjas cistercienses".

La imagen inspirada por el relato tuvo una gran difusión en Europa a partir de I330; franciscanos y mercedarios hicieron suyo ese relato a lo largo del siglo xIV, y durante el XV y el XVI carmelitas y dominicos lo utilizaron con sus respectivas imágenes, la Virgen del Carmen y la del Rosario. El tema tuvo una gran difusión y se representó en retablos, pinturas y tallas de madera en Italia, Alemania y en la Península Ibérica donde, a mediados del siglo xvII, Zurbarán pintaría para los cartujos uno de sus más tardíos ejemplos. Aunque no desapareció por completo (nos quedan esbozos del siglo xviII de la Madonna della Misericordia firmados por Carlo Marata y por Giovanni Battista Tiépolo), su iconografía fue desplazada por el tema de la Nave de la Iglesia la cual, abatida por las olas de un mar embravecido plagado de herejes y demonios, llevaba a los fieles que se acogían a ella al puerto seguro de la salvación.

Mientras la iconografía del manto protector tendió a desaparecer en Europa desde mediados del XviI, en América recibió un gran impulso y comenzó a tomar el nombre de una advocación española: la de la Virgen del Patrocinio. Desde 1656 el papa Alejandro VII instituyó, a instancias de la Corona espańola, una fiesta especial dedicada al Patrocinio de Nuestra Señora el tercer domingo de noviembre y, a partir de entonces, Felipe IV le dedicó una capilla en el palacio-monasterio del Escorial. ${ }^{4}$ Sin embargo, dicha imagen no presentaba el manto propio de los "patrocinios" tradicionales y, aunque fue nulo su

3. Manuel Trens, María. Iconografía de la Virgen en el arte español (Madrid: Editorial Plus Ultra, 1947), 257.

4. Javier Campos Fernández, "La Virgen del Patrocinio y el Monasterio del Escorial", en Advocaciones Marianas de Gloria (Madrid: San Lorenzo del Escorial: 2012), 699-732. 
efecto en las representaciones de la Virgen protegiendo bajo su manto a diversas comunidades, le dio un nuevo nombre a dichas imágenes que proliferaron en América y en especial en la Nueva España. ${ }^{5}$

A diferencia de Europa, con el nombre de "patrocinios" se representó en este territorio no sólo a la Virgen sino también a otros santos; aunque han quedado pocos ejemplos del modelo provenientes del siglo Xvi, su número aumentó al paso del tiempo hasta llegar a un extraordinario auge en el XVIII. Como señala el epígrafe sacado de la descripción de los festejos de dedicación de la capilla del Rosario de Puebla en I690, los "esclavos" de la Señora, protegidos bajo su manto, obtenían de tan "liberal" patrona "crecidos beneficios" con el "menor agasajo". ${ }^{6}$ Con base en dicho modelo se representó a autoridades, corporaciones y familias, y se creó uno de los más ricos documentos sobre la sociedad del virreinato y sobre la percepción que ésta tenía de sí misma. Para enmarcar el ámbito de elaboración de dichas imágenes debo partir precisamente de tales premisas que estaban en la base de las sociedades preindustriales de Occidente.

\section{Familias, estamentos y autoridades}

El primer elemento de diferenciación social, sancionado por las leyes civiles y religiosas, era el estamental, cuya estructura simbólica estaba basada en el esquema familiar patriarcal. Con un Dios Padre a la cabeza, el papa se adjudicó el apelativo de "Santo Padre" y la Iglesia sería denominada en adelante "la Santa Madre". La humanidad se convertía así en un grupo de hermanos de Cristo, pero al mismo tiempo en un rebaño de borregos obedientes a su pastor y de niños necesitados de guía y castigo bajo las órdenes de su Padre. La profesión de las monjas, esposas de Cristo, la paternidad del clero sobre los laicos, llamar a la cabeza de un convento padre prior o madre superiora y a sus miembros hermanos y hermanas y el denominar hermandades a las cofradías, serán otros

5. Existen ejemplos de pinturas de patrocinio, sobre todo de la Virgen, en Perú, Nueva Granada, Ecuador y Brasil, pero no son tan numerosas ni poseen la riqueza iconográfica de las que se dieron en la Nueva España. Comunicación personal con Jaime Humberto Borja, 3 de agosto de 2020 .

6. El sermón lo publicó Gorozpe O. P., Octava Maravilla del Nuevo mundo en la gran capilla del Rosario. 


\section{DOI: https://doi.org/10.22201/iie.18703062e.2021.119.2760}

I74

ANTONIO RUBIAL GARCÍA

tantos temas en los que se utilizaba el parentesco como símbolo de unidad y sujeción. La presencia de la Virgen respondía también a esa lógica "familiar" y muy pronto la Iglesia comenzará a asociarse con ella como madre, pero también como la esposa de Cristo. La argamasa que permitía el funcionamiento de esa gran familia era la caridad, con cuyo ejercicio cotidiano se eliminaría todo abuso, aunque de sus "beneficios" estaban excluidos aquellos que pertenecían a la "estirpe" de Satán: herejes, brujas, homosexuales, musulmanes y judíos. ${ }^{7}$

El tema del amor fraterno estaba también en la concepción de la sociedad cristiana, la cual desde el siglo x se consideraba formada por tres "órdenes" instituidas por Dios: clérigos (oratores), nobles (bellatores) y campesinos (laboratores). Los primeros, creadores del esquema, se adjudicaron la paternidad sobre los otros dos (a los sacerdotes se les llamaba "padres"), aunque a menudo esta primacía les era disputada por los nobles. El término "orden” se definía a partir de los privilegios, con lo cual los trabajadores agrícolas y los pobres urbanos fueron asimilados a la plebe del antiguo sistema romano. Por la riqueza que acumulaban y los servicios prestados a la incipiente monarquía, mercaderes y funcionarios buscaron diferenciarse de los plebeyos y conseguir el favor del rey, comprando tierras, ingresando a sus hijos en los sectores eclesiásticos y estableciendo vínculos matrimoniales con la nobleza.

De los dos estamentos privilegiados el clero era el más claramente definido, por su fuero de intocabilidad y por contar con tribunales especiales para juzgar a sus miembros. Las diversas instituciones en las que participaban los clérigos eran además vías para el ascenso social, pues a ellas pertenecían individuos de todos los sectores. Para marcar su diferencia con el resto de los mortales, los clérigos ostentaban su celibato como signo de superioridad.

El otro estamento privilegiado era la nobleza y a ella se accedía por herencia (se nacía noble) o por una concesión del rey para premiar hazañas militares y servicios a la Corona. Los nobles poseían el título de don y un apellido que definía su linaje; eran los únicos que podían portar armas y montar a caballo, de ahí su denominación de caballeros. Sin embargo, en la nobleza había una distinción que derivaba del patrimonio asociado al linaje; por ello los hidalgos pobres se diferenciaban de los marqueses, los condes y los duques, títulos otorgados por el rey y avalados por extensas posesiones (patrimonio) y por la memoria de pertenecer a un linaje "ilustre". A pesar de esas diferencias

7. Jérôme Baschet, La civilización feudal. Europa del año mil a la colonización de América (Ciudad de México: Embajada de Francia/Fondo de Cultura Económica, 2018), 520 -530. 
todos los nobles tenían algunos privilegios comunes: no podían ser hechos prisioneros por deudas ni tampoco ser castigados en público.

Desde el siglo XII, las monarquías emergentes comenzaron a insertarse en dicho esquema estamental y familiar en su intento por sujetar a los municipios urbanos, a la nobleza y a los obispos. El incipiente Estado protegió a los estamentos privilegiados con leyes especiales, fueros y exenciones tributarias, les permitió participar en los órganos de representación "ciudadana" (las cortes en la Península Ibérica) y, a veces, les concedió juzgados propios, como sucedió con los eclesiásticos. Asimismo, los integró dentro de sus aparatos de poder y delegó en ellos funciones de su autoridad. Por la presencia de obispos entre estos cuadros y para agilizar la labor evangelizadora que Espańa realizaba en América, el papado había hecho varias concesiones a sus reyes con el llamado Regio Patronato indiano, entre las que estaba la posibilidad de nombrar a los obispos de Indias y de autorizar la fundación de templos y conventos.

Con la formación de los grandes conglomerados imperiales entre los siglos XV y xvi, fue necesario ampliar el número de funcionarios y delegar en nobles y clérigos muchas de las funciones de gobierno. En el imperio espańol, que dominaba extensos territorios a ambos lados del Atlántico, el rey constituía un símbolo de unidad, pero el gobierno lo ejercían virreyes, oidores, gobernadores y obispos, quienes eran sometidos a diferentes controles por parte del rey, de sus consejeros y de los límites impuestos por una visión jurídico-teológica del mundo.

Ese sistema jerárquico tenía a Dios a la cabeza y las autoridades terrenales lo representaban de modo que todos los habitantes de un reino eran considerados vasallos de un monarca y ovejas de un rebaño cuyo pastor era el Sumo Pontífice. Esta sociedad cristiana formaba la Iglesia militante que luchaba en la tierra contra las fuerzas infernales y que recibía la ayuda constante de la Iglesia triunfante, formada por ángeles y santos que habitaban en los cielos, y que podía comunicar sus beneficios espirituales a la Iglesia purgante que penaba en el purgatorio sus culpas en espera de la gloria.

En los cuadros de patrocinio la autoridad estaba representada en esa "Iglesia del cielo", con la Trinidad y la Virgen ostentando los atributos del poder: coronas y cetros. A partir de la segunda mitad del siglo xviII comenzaron también a aparecer bajo los mantos protectores el rey y el papa, los gobernadores y los obispos, encabezando a los fieles (casi siempre nobles) y a los clérigos de la Iglesia militante. En dichos cuadros, un elemento fundamental de diferen- 


\section{DOI: https://doi.org/10.22201/iie.18703062e.2021.119.2760}

176

ANTONIO RUBIAL GARCÍA

ciación estamental era el vestido. Los clérigos portaban un traje especial y cada orden religiosa se distinguía por el color del hábito usado por sus miembros. Además, la tonsura, un corte de cabello en la coronilla, los diferenciaba de los laicos. Los nobles se distinguían de los plebeyos por el uso de determinados atuendos (vistosas casacas, espadas "de vestir", entre otros) y numerosas leyes, sobre todo en América, exigían el respeto a estas convenciones y prohibían que mestizos e indios "del común" vistieran como los españoles.

\section{El sistema clientelar, el corporativismo $y$ las representaciones de "sumisión"}

El tema del patronazgo, central en las representaciones que estamos estudiando, remite a una antigua tradición romana que pervivió a lo largo de la Edad Media y que modeló las relaciones sociales durante casi dos mil años. Como lo ha mostrado Antonio Feros en un artículo seminal sobre el clientelismo, tanto los vínculos de los cortesanos con el rey, como aquellos que establecían los nobles con sus allegados de menor rango, estaban marcados por esas relaciones de dependencia y colaboración. El esquema clientelar se extendía hasta el cielo, pues los santos eran vistos como patronos de sus fieles, y desde ahí descendía a la corte, donde el monarca era comparado con Dios, pues protegía y preservaba a sus funcionarios, considerados "criaturas" y "hechuras" suyas. ${ }^{8} \mathrm{Sin}$ embargo, la gran distancia que separaba al soberano terrenal del celestial debía remarcarse con signos externos. Ante el rey, el súbdito ponía sólo una rodilla en el piso, pero ante Dios, presente en la Eucaristía, o ante la Virgen Reina, arrodillarse con ambas constituía el mayor signo de sumisión.

Los vínculos clientelares constituían también mecanismos de diferenciación social, sobre todo si tenemos en cuenta la rigidez jerárquica que consideraba plebe a la mayor parte de la población. En la sociedad novohispana, donde las diferencias étnicas eran muy marcadas, funcionaba este criterio y entre los indígenas los había nobles y macehuales. A pesar de la distancia existente entre la nobleza y el vulgo, el ascenso social era posible por medio de los vínculos

8. Antonio Feros, "Clientelismo y poder monárquico en la España de los siglos Xvi y xviı", Relaciones, Estudios de Historia y Sociedad XIX, núm. 73 (invierno 1998): 17-49. Una de las obras más influyentes a este respecto fue el De Officiis de Marco Tulio Cicerón, quien definió las "intenciones" que había detrás del clientelismo: el honor, la fidelidad, la protección de intereses personales o las expectativas de obtener beneficios económicos. 
clientelares, los méritos obtenidos por servicios a la Corona, el estudio en centros universitarios, la dedicación al comercio o a las profesiones "liberales", o el ingreso a una institución eclesiástica.

Aunque la plebe no tenía por sí misma ningún privilegio estamental, podía ejercer sus derechos, cumplir obligaciones y dirimir disputas ante el monarca dentro del otro sistema que organizaba la sociedad que era el corporativismo. Las corporaciones eran, además, el medio para recibir asistencia social e incluso obtener ascenso personal, poseían un esquema jurídico (sus estatutos), tenían mecanismos de elección de sus autoridades y sus propios visitadores, es decir, instrumentos de autorregulación.

$\mathrm{Al}$ igual que los estamentos, las corporaciones poseían signos externos, lugares y espacios donde actuaban y una serie de aparatos de representación: vestuarios propios para las fiestas, santos patronos, estandartes y escudos de armas. Sus ámbitos eran centros de convivencia, pero también espacios forjadores de sociabilidad y civilidad, gracias a que el manejable número de sus miembros les permitía interactuar entre sí en proyectos comunes y con otras instancias.

Las corporaciones mejor organizadas eran las provincias religiosas las cuales, con su maquinaria propagandística, buscaban conseguir apoyos económicos, influencia política, vocaciones y la admiratio de los miembros de las otras órdenes y de la sociedad. Para conseguir dichos objetivos las instituciones religiosas marcaban su presencia urbana por dos medios: los magníficos templos y conventos, espacios que daban sus nombres a los barrios; y la fiesta que, con sus misas y procesiones, constituía el medio más idóneo para "teatralizar" y "sacralizar" la jerarquización social. También servía como propaganda de esas corporaciones la exaltación de los logros de sus miembros destacados por medio de crónicas, de retratos y de las aquí estudiadas imágenes de patrocinio. Con todo ello, además del prestigio hacia afuera, se buscaba la cohesión e identidad hacia el interior, por lo que eran parte central de la educación de los jóvenes frailes que ingresaban en ellas. Por otro lado, la necesidad de guardar su memoria colectiva para ser transmitida oral o visualmente a las nuevas generaciones, propició la creación de galerías de retratos y de archivos. ${ }^{9}$ Estos últimos eran fundamentales para las provincias pues una buena parte de sus

9. Paula Mues Orts, "Corporate Portraiture in New Spain. Social Bodies, the Individual, and Their Spaces of Display", en New England/New Spain. Portraiture in Colonial Americas (I492-1850), Donna Pierce, ed. (Denver: Mayer Center for Pre-Columbian and Spanish Colonial Art at Denver Art Museum, 20I4), 8I-IOO. 


\section{DOI: https://doi.org/10.22201/iie.18703062e.2021.119.2760}

178

ANTONIO RUBIAL GARCíA

privilegios podía ser defendida gracias a esa memoria documental resguardada en ellos. ${ }^{\text {IO }}$

Frente a la verticalidad del sistema clientelar, el corporativismo se definía por su horizontalidad y ambos sentidos se utilizaron para representar a la sociedad y su relación con el cielo. La iconografía que mostraba con mayor eficacia dicho esquema fue sin duda la de los patrocinios. La representación de la Virgen de la Misericordia llegó a América con los misioneros, quienes la adaptaron y propusieron también a sus santos como portadores de los mantos protectores. Esas primeras representaciones del patrocinio aparecidas en la Nueva España desde la segunda mitad del siglo xvi, fueron producto de una época de profundos cambios, tanto en los imperios hispánico y lusitano como en sus posesiones transatlánticas.

\section{Los patrocinios novohispanos en los siglos XVI y XVII}

Mientras en Europa la presencia de la reforma protestante impulsaba el movimiento católico de la Contrarreforma y el rey Felipe II se enfrentaba a una crisis financiera y a guerras continuas, la Nueva España era asolada por devastadoras epidemias que se abatían sobre las comunidades indígenas. Con todo, la apertura de las rutas comerciales del Pacífico, la expansión y consolidación de las haciendas y los descubrimientos de ricas vetas de plata en el norte generaban enormes fortunas. Esto benefició a las nuevas instituciones como el tribunal del Santo Oficio, la Compañía de Jesús, las provincias religiosas de carmelitas, mercedarios y dieguinos, los monasterios femeninos, la universidad y una enorme gama de cofradías y hermandades, todos ellos apoyados por los obispos y sus cabildos catedralicios.

Frente a estas nuevas corporaciones eclesiásticas, que abrían las ciudades a la recepción de las políticas culturales propuestas por la Contrarreforma, las viejas órdenes mendicantes evangelizadoras luchaban por conservar los privilegios obtenidos al haber sido las primeras en llegar a la Nueva España, se

Io. Antonio Rubial García, "Las órdenes mendicantes evangelizadoras en Nueva España y sus cambios estructurales durante los siglos virreinales", en La Iglesia en Nueva España. Problemas y perspectivas de investigación, Pilar Martínez López-Cano, coord., Serie Historia Novohispana, 83 (Ciudad de México: Universidad Nacional Autónoma de México-Instituto de Investigaciones Históricas, 2010), 215-236. 
adaptaban a las condiciones impuestas por el cambio y enfrentaban a los obispos que pretendían obtener el control de las doctrinas indígenas. Para hacer patente su presencia como cuerpos sociales y para enfrentar las pretensiones de los obispos, estas órdenes misioneras se hicieron visibles por medio de la impresión de sus sermones y crónicas, de sus templos y conventos, de sus escudos y árboles genealógicos, de su participación en las fiestas y procesiones y de su santoral. Desde su llegada a América en el siglo XVI, franciscanos, dominicos y agustinos impusieron su presencia al poner a los pueblos indígenas bajo la protección de sus santos, cuyos nombres marcaron la toponimia del continente. Lo mismo hacían los cabildos de las ciudades de españoles que juraban como sus patronos a los mendicantes canonizados, los invocaban contra las catástrofes y epidemias y ponían sus gremios y cofradías bajo su amparo. ${ }^{\text {II }}$

A partir de la metáfora de Jerusalén, las ciudades novohispanas organizaron su espacio social como una representación del cielo. Ángeles y santos se convirtieron en los principales instrumentos en la conformación de las identidades sociales, tanto por parte de los ayuntamientos como del resto de las corporaciones (gremios, cofradías, provincias religiosas, universidad, consulado, entre otros). En la dedicación de los templos y en las fiestas del año litúrgico, fungieron como instrumentos fundamentales de sus aparatos de representación y se constituyeron en símbolos que cohesionaron a los miembros de las distintas instancias que conformaban en entramado social urbano.

Varios ejemplos de la segunda mitad del siglo XVI muestran a esos santos mendicantes como protectores de comunidades monacales o de caciques indígenas. Éste es el caso de un ejemplo franciscano en el retablo mayor del templo parroquial de Xochimilco donde san Bernardino de Siena, el tutelar de la iglesia, se representa cobijando bajo su manto protector a los miembros de su cofradía: hombres y mujeres de la nobleza indígena (arrodillados y con rasgos muy occidentales) y un personaje barbado que, al estar vestido a la española representa a ese sector (fig. I).

Lo más común, sin embargo, fue mostrar a la comunidad religiosa bajo la capa extendida de su patrono, santo Domingo o san Agustín. Este último está representado en dos relieves que aún adornan las fachadas de los templos agustinos en la Ciudad de México y en Oaxaca, ambas ya del siglo xviı. El obispo

II. Pierre Ragon, "Los santos patronos de las ciudades del México central (siglos xVI y XVII)”, Historia Mexicana LII, núm. 2 (octubre-diciembre 2002): 36I-389. 
DOI: https://doi.org/10.22201/iie.18703062e.2021.119.2760

I80

ANTONIO RUBIAL GARCÍA

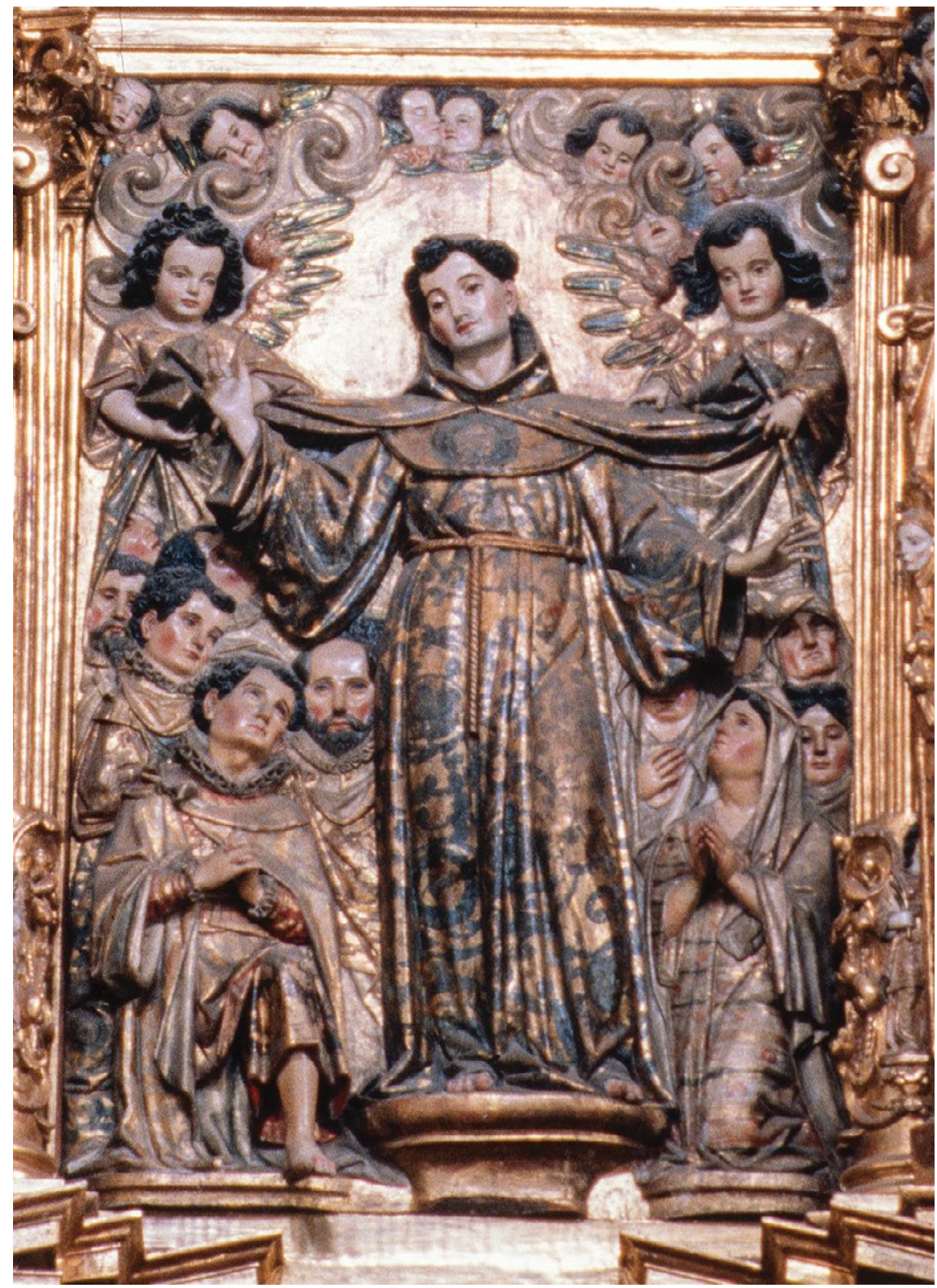

I. Anónimo, San Bernardino de Siena protege a la nobleza indígena, relieve del retablo mayor de la iglesia de San Bernardino, alcaldía de Xochimilco, Ciudad de México. Archivo Fotográfico "Manuel Toussaint", Instituto de Investigaciones Estéticas, UNAM. 


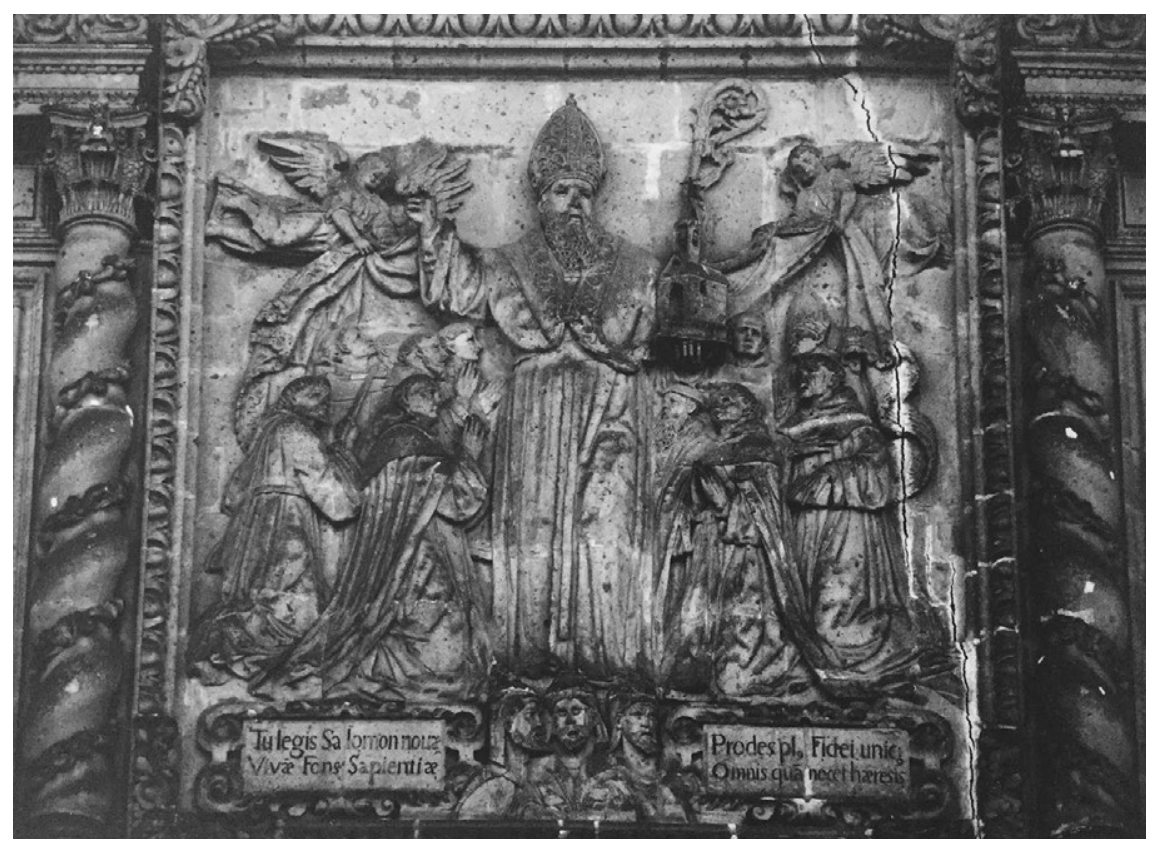

2. Anónimo, San Agustín protege a su congregación, relieve de la portada del ex templo de San Agustín en la Ciudad de México, sede de la antigua Biblioteca Nacional. Tomado de Carlos Martínez Assad, Rescate de San Agustín (Ciudad de México: Universidad Nacional Autónoma de México-Dirección del Patrimonio Universitario, 20I2), 8.

de Hipona porta en sus manos los atributos de doctor de la Iglesia (tiara y catedral), tiene a sus pies las cabezas de tres herejes (Manes, Pelagio y Donato) y protege bajo su manto a los miembros de su orden arrodillados (fig. 2). Esta imagen ilustra la portada de un libro del insigne fray Alonso de la Veracruz (su Phisica Speculatio), impreso en México en 1557.

A principios del siglo XviI, las nuevas órdenes llegadas a finales de la centuria anterior también emplearon el esquema del patrocinio de sus santos como discurso para hacer patente su presencia social. El ejemplo más interesante es un gran lienzo de autor anónimo que representa a santa Teresa iluminada por la luz de la paloma del Espíritu Santo volando sobre su cabeza y con el corazón traspasado por la flecha del amor divino en el centro de su pecho, tema de una de sus visiones descrita por ella misma y conocida como la transverberación. La santa recién canonizada en I622 sostiene en una de sus manos una 


\section{DOI: https://doi.org/10.22201/iie.18703062e.2021.119.2760}

I82

ANTONIO RUBIAL GARCÍA

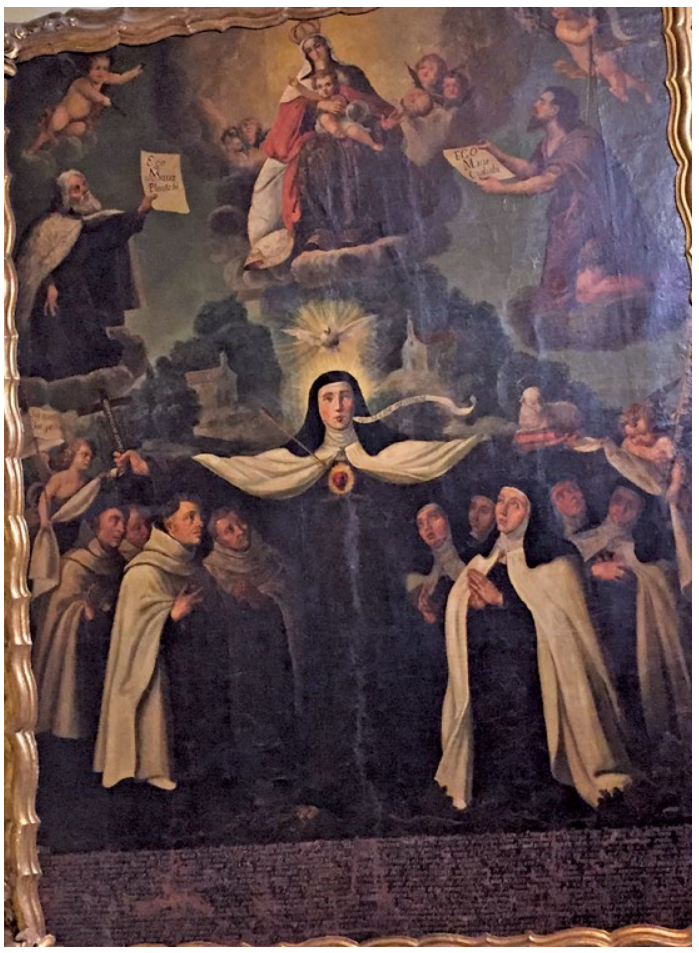

3. Anónimo, Patrocinio de santa Teresa sobre su orden, Museo de la Basílica de Guadalupe, alcaldía Gustavo A. Madero, Ciudad de México. Foto del autor. D.R. (C) Archivo del Museo de la Basílica de Guadalupe.

cruz y en la otra un cordero que reposa sobre el libro de los Evangelios. Dos angelitos ayudan a sujetar los extremos del manto que protege a los miembros de las ramas masculina y femenina de la orden reformada por la santa de Ávila, a quienes se representa arrodillados y con las manos juntas en señal de oración y vasallaje hacia su patrona. Desde el cielo, una Virgen del Carmen coronada sostiene en su regazo a un niño Jesús con el globo terráqueo. A sus lados, san Elías (el fundador mítico de la orden) y san Juan Bautista, colocado sobre el cordero de Dios al que sirvió de precursor, simbolizan el espíritu eremítico con que fue "fundada" la orden en el monte Carmelo (fig. 3).

El número de representaciones de los siglos XVI y XVII del tema del "patrocinio" que han llegado hasta nosotros no es abundante, quizá porque muchas obras de ese periodo se han perdido. Podemos en cambio aseverar que, en contraste, del centenar de obras conservadas, la gran mayoría se elaboraron a lo largo del siglo XviII. 


\section{Las imágenes novohispanas de patrocinio durante el conflictivo Siglo de las Luces}

Mientras que en las centurias anteriores el protagonismo de los santos fundadores compitió con las representaciones de los patrocinios de las Vírgenes, el tema de los mantos protectores de las advocaciones marianas más prestigiosas se volvió lo predominante en el xviII. En dicha centuria, un número indeterminado de estas obras debió estar en ámbitos domésticos y tuvo fines devocionales, de ahí su pequeño formato. Pero una cantidad considerable de las que han llegado a nosotros (aquellas de las que nos vamos a ocupar ahora) fueron encargadas por las corporaciones religiosas para ser colocadas en espacios de visibilidad y tenían una clara finalidad propagandística. Por otro lado, al estar situadas en alto y, dado su gran tamaño, obligaban al observador a levantar la vista y, desde esa posición rebajada, lo integraban al espacio de sumisión representado bajo el manto protector de las imágenes propias de cada orden. ${ }^{12}$

Es muy significativo, además, que tal difusión del modelo se hiciera más evidente en una época tan difícil para las corporaciones religiosas como lo fue la era borbónica. Un anticlericalismo creciente las juzgaba improductivas y a menudo se exageraban sus vicios para darle mayor énfasis a su inutilidad, más negativa aún por el acrecentado patrimonio que poseían. Pero incluso aquellos que las consideraban necesarias las criticaban porque habían perdido su carisma original y postulaban ineludible su reforma para restituir en sus miembros los ideales de pobreza, estudio y oración con los que habían sido fundadas. ${ }^{13}$

Anticlericalismo y reformismo se vieron acentuados en América a causa de la cuestionada presencia de algunas de las órdenes en la administración parroquial de muchas comunidades indígenas y por las luchas de alternativa que enfrentaron a criollos y peninsulares. Por ello, desde la subida al trono de la casa borbónica se implantó una serie de reformas las cuales comenzaron a limitar los privilegios de los religiosos en Indias con miras a reforzar al clero

I2. Paula Mues ha desarrollado esta idea respecto a los retratos corporativos, a su presencia en galerías y al importante papel que tuvieron como instrumentos generadores de identidad. "Corporate Portraiture", 87-100.

13. Antonio Rubial García, "Las reformas de los regulares novohispanos anteriores a la secularización de sus parroquias (1650-1750)", en Reformas y resistencias en la Iglesia novohispana, Pilar Martínez López Cano y Francisco Cervantes Bello, coords. (Ciudad de México: Universidad Nacional Autónoma de México-Instituto de Investigaciones Históricas/Benemérita Universidad Autónoma de Puebla-Instituto Alfonso Vélez Pliego, 2014), I43-I66. 


\section{DOI: https://doi.org/10.22201/iie.18703062e.2021.119.2760}

I84

ANTONIO RUBIAL GARCÍA

secular y al episcopado. Éste no sólo tendió a ejercer mayores controles sobre los regulares, sino que consiguió también secularizar a la mayor parte de las doctrinas de indios que los religiosos administraban. Pero incluso las órdenes que no tenían injerencia con los naturales, como mercedarios y carmelitas, se vieron afectadas por la presencia de visitadores reformadores peninsulares que pretendían regresar a sus institutos a la observancia rigurosa de sus reglas, por considerar que la abundancia de elementos criollos en las provincias americanas había debilitado el espíritu original con el que fueron fundadas las misiones en el continente.

Conforme las reformas borbónicas se radicalizaban, sobre todo después de que la secularización general de las doctrinas fue irreversible y que se consumó la expulsión y extinción de la Compañía de Jesús, frente a esas políticas y en abierta confrontación con los obispos, las órdenes religiosas impulsaron su presencia en las ciudades novohispanas a partir de la exposición de sus santos emblemáticos en fiestas, sermones, impresos hagiográficos e imágenes. Este santoral servía para mostrar su carácter de elegidos de Dios, y exaltaba a sus miembros como seguidores de una espiritualidad modélica, detentadores de una sabiduría teológica y mística sublime y necesarios para toda sociedad que se llamara católica.

A mediados del siglo xvin funcionaban en los territorios de la Nueva España y Guatemala, además de 63 monasterios femeninos, cinco órdenes mendicantes distribuidas en 17 provincias, cuatro colegios franciscanos de Propaganda Fide, tres congregaciones de frailes hospitalarios y la Compañía de Jesús, cuya única provincia ejercía su ministerio en II3 misiones y 26 colegios. Junto con ellas, en II catedrales funcionaban cabildos eclesiásticos, cuyas "dignidades" y canónigos se hacían cargo de las funciones litúrgicas y de la administración de los diezmos. La mayor parte de estas instituciones utilizaron el corporativismo y el clientelismo como argumentos para acreditar su importancia social, y desplegaron las representaciones de sus comunidades bajo los mantos protectores del patrocinio de la Virgen o de san José.

Estas imágenes, fundamentales para afianzar a las corporaciones religiosas, estuvieron colocadas, y en ocasiones aún lo siguen estando, en espacios que son para nosotros un importante referente de su funcionalidad. A menudo muchas de ellas están o estuvieron dentro de los templos, muy posiblemente entre las órdenes religiosas fue lo más común. Otras veces estaban en las sacristías catedralicias o al interior de los edificios conventuales, por lo que funcionaban no sólo como instrumentos para manifestar la presencia de la institución hacia 
afuera, constituían también elementos de identidad hacia el interior de la corporación. Además, era común que estos cuadros formaran parte de conjuntos simbólicos, es decir, que dialogaran con otras obras que estaban en el mismo espacio y que complementaban sus sentidos discursivos. ${ }^{\text {I4 }}$

\section{Los patrocinios de las órdenes religiosas o la defensa de una causa perdida}

En el siglo XviII novohispano casi todas las órdenes religiosas (a excepción de los agustinos y los hospitalarios) multiplicaron en obras de gran formato la representación de sus respectivos institutos bajo los mantos extendidos de las Vírgenes del Carmen, del Rosario, de la Merced, de la Inmaculada Concepción o de la Virgen de Guadalupe. Fue también notable cómo la extendidísima devoción al patriarca san José tomó a veces la forma del patrocinio protector de los jesuitas. Más escasos, pero aún presentes en el siglo XviII, tenemos ejemplos de santos, como Francisco o Jerónimo, representados cubriendo bajo su manto a los miembros de sus respectivas órdenes.

Uno de los esquemas que tuvo mayor popularidad entre ellas fue el que mostraba a la Virgen "titular" de cada instituto cuyo extendido manto fungía como elemento de separación entre los espacios celestial y terreno. Arriba, los seres de la Iglesia triunfante cercanos a la Virgen y a la Santísima Trinidad (ángeles, santos y en especial la "parentela de María") aparecían rodeados de nubes y de luz, portando sus atributos simbólicos y en posiciones exaltadas. Abajo, en contraste, el ámbito de los receptores de tales beneficios, los miembros de las órdenes y sus allegados, se representaban en colores menos intensos, de rodillas y con actitudes de sumisión. Sin embargo, también era frecuente mostrar a los santos entre sus correligionarios y encabezando con la misma actitud orante al común de los mortales. Así aparecían los fundadores de las órdenes,

I4. Paula Mues ha hecho importantes aportaciones a este respecto. En su estudio sobre el pintor José de Ibarra trabajó varias de sus obras en sus contextos simbólico-espaciales. Es especialmente interesante su examen de la capilla relicario dedicada a san José en el templo de los jesuitas de Tepotzotlán, donde los lienzos de la huida a Egipto y el "tránsito" dialogan con el patrocinio del santo sobre la Compañía, cuadro que se analizará en este ensayo más adelante. Véase Paula Mues Orts, El pintor novohispano José de Ibarra: imágenes retóricas y discursos pintados, 4 vols., tesis de doctorado en Historia del Arte (Ciudad de México: Universidad Nacional Autónoma de México-Facultad de Filosofía y Letras, 2009), 185-189. Puede consultarse en: www.tesis.unam.mx. 


\section{DOI: https://doi.org/10.22201/iie.18703062e.2021.119.2760}

I86

ANTONIO RUBIAL GARCÍA

y era claro el mensaje de que la protección celestial de dichos santos se reforzaba por su presencia en la tierra.

La mayor parte de los ejemplos de este género sólo muestra a los miembros de las órdenes religiosas, pero hay uno excepcional en el cual, además de estar presente este sentido corporativo y clientelar, se manifiesta claramente la dimensión estamental de la sociedad al incluir en él a los laicos. El lienzo, que se encuentra en el templo de los mercedarios de la villa de Atlixco, cerca de la ciudad de Puebla, tiene como su centro a la Virgen de la Merced, "madre de todos", y se encargó para agradecerle su "protección” a raíz de la gran epidemia de 1762. Su autor, el pintor mulato José Joaquín Magón, puso en el centro del cuadro a María, quien porta el escapulario de la orden mercedaria y un gran manto sostenido por su parentela: el esposo san José, sus padres san Joaquín y santa Ana y su "sobrino" san Juan Bautista. Los flanquean los arcángeles antipestíferos Miguel y Rafael. Desde el cielo y a los lados de la Santísima Trinidad observan la escena cuatro santos sanadores popularizados por los jesuitas: san Cayetano, santa Rosalía de Palermo, san Juan Nepomuceno y santa Gertrudis. ${ }^{\text {IS }}$

La novedad, sin embargo, se encuentra bajo el manto, donde a los lados de la Virgen se muestran los diversos sectores sociales. A la derecha de la patrona, los mercedarios van encabezados por su fundador Pedro Nolasco, a quien acompañan dos niños cautivos en representación de los redimidos por una orden que se enorgullecía de dicho carisma. Del otro lado, algunos clérigos y un grupo de hombres y mujeres españoles, ataviados como nobles, muestran su agradecimiento y devoción de rodillas, mientras uno de ellos, de pie, señala a una familia de la nobleza indígena que ha sido librada de la peste. Lo que hace excepcional al cuadro de Magón y lo diferencia del resto de los de su género, son las figuras de los beneficiados que aparecen de pie en un segundo plano: detrás de los mercedarios, varios franciscanos y un grupo de monjas, y como corifeos de los nobles, hombres y mujeres de la plebe mestiza (fig. 4).$^{16}$

15. Alejandro Andrade Campos, El pincel de Elías. José Joaquin Magón y la orden de Nuestra Señora del Carmen (Puebla: Benemérita Universidad Autónoma de Puebla, 2015), 220.

I6. Un excelente estudio de dicha imagen en Jaime Cuadriello, "Politización y sociabilidad de la imagen pública. Del rey y sus cuerpos (I700-I790)", en Pintado en México, I700-I790, Jaime Cuadriello, Ilona Katzew, Paula Mues y Luisa Elena Alcalá, eds. (Ciudad de México: Fomento Cultural Banamex, 20I7), II2-I39, particularmente, I33-I34. Sin duda la excepcionalidad del cuadro de Magón sea consecuencia del carácter de exvoto que posee, pero quizás también influyó el origen étnico del pintor. 


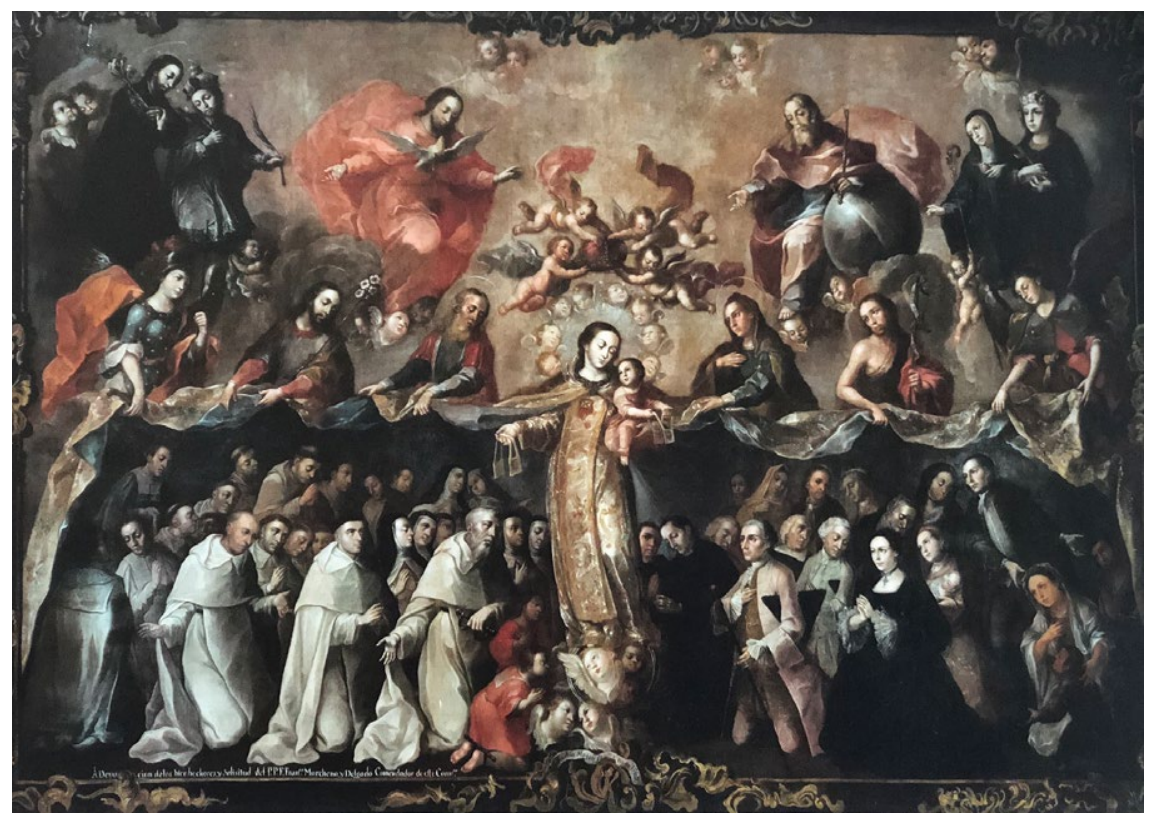

4. José Joaquín Magón, Patrocinio de la Virgen de la Merced sobre la orden y los fieles, templo de la Merced, Atlixco, estado de Puebla. Tomado de Ilona Katzew, Jaime Cuadriello, Paula Mues y Luisa Elena Alcalá, Pintado en México (I700-I790). Pixit Mexici (Ciudad de México y Los Ángeles: Fomento Cultural Banamex/Los Angeles Country Museum of Art, 2017), I34.

En la misma villa de Atlixco, la Virgen de los mercedarios y su escapulario tenían una fuerte competencia en el templo del Carmen, administrado por una orden que desde el siglo Xvir hizo un extensivo uso de este tipo de representaciones, y es dicha corporación la que ha dejado el mayor número de ejemplos de patrocinios. Todos ellos están vinculados a la promoción de la Virgen del Carmen y de su escapulario y a las cofradías encargadas de su culto. Marcela Corvera ha señalado que en varias de esas imágenes los beneficiados no son los miembros de la orden sino las ánimas del purgatorio, pues el escapulario carmelita se consideraba un eficiente instrumento para librar a sus devotos de una prolongada estancia en ese lugar. ${ }^{17} \mathrm{Al}$ representarse a las almas como cuer-

17. Marcela Corvera Poiré fue una de las primeras investigadoras en tratar el tema de los patrocinios en su tesis "El patrocinio. Interpretaciones sobre una manifestación artística novohispana”, tesis de licenciatura en Historia (Ciudad de México: Universidad Nacional Autónoma de México-Facultad de Filosofía y Letras, 1991), 47-59. 


\section{DOI: https://doi.org/10.22201/iie.18703062e.2021.119.2760}

I88

ANTONIO RUBIAL GARCÍA

pos desnudos, desaparece la diferenciación social cuya principal marca era el vestido. Salvo la presencia indispensable de algunos símbolos de autoridad, como tiaras y coronas, el purgatorio y el infierno son los únicos espacios donde desaparecen las diferencias estamentales y corporativas y en los que el sufrimiento trae igualdad.

Entre los muchos lienzos sobre la protección de la Virgen del Carmen pintados en el XVIII, destacan dos muy similares en composición y factura, ambos de la autoría del pintor poblano Luis Berrueco. Uno de ellos se encuentra en el templo de la Natividad en la mencionada villa de Atlixco; el otro, que también procede de Puebla como lo declara una inscripción, está en la capilla de Jesús Nazareno del templo conventual de San Ángel en la Ciudad de México. En los dos lienzos, la Virgen se representa con el niño en brazos, portando en una mano el famoso escapulario de la orden y cubriendo con su manto a la comunidad carmelitana. ${ }^{18}$

El despliegue de la descomunal pieza de tela se sostiene, en ambos cuadros, gracias a la ayuda, de nuevo, de la parentela de la Virgen, mientras un grupo de ángeles revolotea sobre su cabeza y sostiene su corona. Debajo del manto están colocados de manera jerárquica y por género los miembros de la orden, encabezados por sus santos fundadores. Detrás de Teresa de Ávila, a cuyos pies se encuentra su infaltable birrete doctoral, están las religiosas, mientras que a san Elías (el mítico iniciador de la orden) y a san Juan de la Cruz (también con birrete) los sigue la comunidad masculina en compañía de un laico, muy posiblemente el donante (fig. 5). ${ }^{19}$

Los dominicos, por su parte, difundieron también la imagen del patrocinio de "su Virgen", la del Rosario, gracias a las archicofradías que funcionaban en todos sus templos y que promovían dicha práctica que, según una tradición apócrifa, fue revelada por la misma Virgen al fundador Domingo de Guzmán. ${ }^{20}$ En I57I Espańa y otros reinos cristianos la proclamaron protectora de

18. Andrade, El pincel de Elías, 48-I49.

19. Antonio Rubial García, "El birrete de Santa Teresa y la ciencia infusa. Creación y expansión de un nuevo modelo femenino en el arte novohispano", Anales del Instituto de Investigaciones Estéticas XL, núm. II2 (2018): 99-I3I.

20. La práctica del Rosario y el culto a esta advocación fue iniciativa del dominico bretón fray Alain de la Roche (Alanus de Rupe), quien en 1470 escribió De utilitate psalterii Mariae, obra traducida a todas las lenguas europeas. En I475 fray Jacques Sprenger, prior del convento dominico de Colonia instituyó en esa ciudad la primera cofradía del Rosario, aprobada por bula pontificia en 1478 . 


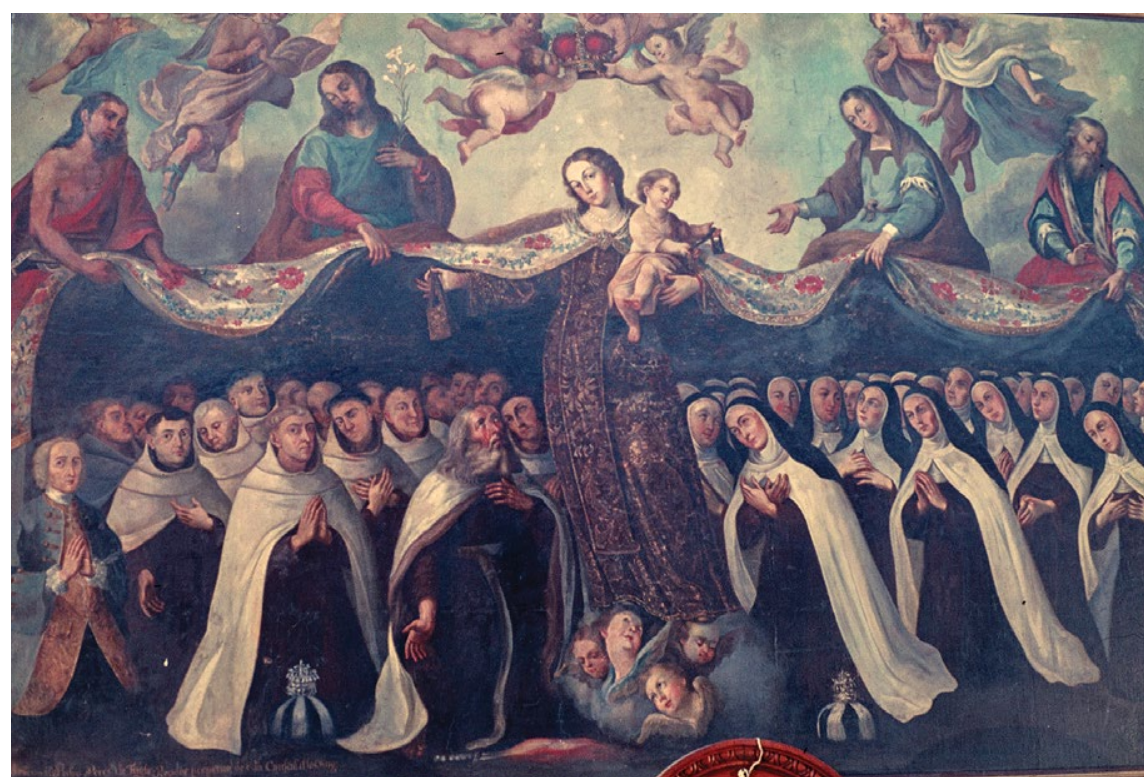

5. Luis Berrueco, Patrocinio de la Virgen del Carmen sobre su orden, templo del Carmen de San Ángel, alcaldía Álvaro Obregón, Ciudad de México. Archivo Fotográfico "Manuel Toussaint”, Instituto de Investigaciones Estéticas, UNAM.

los navegantes y de la monarquía a raíz de la victoria cristiana sobre la armada turca en la batalla de Lepanto. Después de esto, en muchos de los templos de la orden en todo el mundo católico se abrió una capilla anexa dedicada a fomentar su culto, asociado con el de Santa María de las Victorias. En I573 el papa Gregorio XIII expidió la bula Monet Apostolus por la que se instauraba la conmemoración de la batalla de Lepanto para el primer domingo de octubre, fecha en la cual los cófrades del Rosario celebraban su fiesta. ${ }^{2 \mathrm{I}}$

Desde el siglo XVII se volvió una representación muy común en la Nueva España mostrar a dicha Virgen con el niño Jesús en su regazo o en sus brazos sosteniendo un rosario y protegiendo bajo un enorme manto azul a los santos de la orden y a las comunidades masculinas y femeninas sujetas a la regla dominica. Dicha imagen quedaba avalada por una leyenda según la cual san-

2I. Víctor Mínguez Cornelles, “Auxiliorum Habsburgicum. La Virgen del Rosario y Lepanto", en La piedad de la casa de Austria: arte, dinastía y devoción, Víctor Mínguez e Inmaculada Rodríguez Moya, coords. (Gijón: Trea, 2018), 39-62. 


\section{DOI: https://doi.org/10.22201/iie.18703062e.2021.119.2760}

190

ANTONIO RUBIAL GARCÍA

ta Brígida de Suecia, en su libro de las Revelaciones narraba que santo Domingo, en su lecho de muerte, recibió la visita de la Virgen quien le dijo: "quiero bajo mi ancho manto defender y gobernar a tus hijos; todos los que se pongan bajo tu regla serán salvados [...] todos los que busquen refugio bajo los pliegues de mi misericordia recibirán protección". ${ }^{22}$

Un ejemplo de este modelo, realizado en las primeras décadas del siglo XVIII, se encuentra en el templo de Santo Domingo de Oaxaca, cabeza de la provincia de San Hipólito y uno de los más soberbios edificios construidos por la orden en la Nueva España. En su cúpula se puede admirar una espléndida escena en relieve de estuco policromado donde la Virgen del Rosario coronada y rodeada con una aureola de rayos dorados cubre bajo su manto protector, sostenido por seis angelitos, a los santos más populares de la orden: a su derecha el papa recién canonizado (I7I2) Pío V, promotor del culto a la Virgen del Rosario; junto a él, el fundador Domingo de Guzmán y el inquisidor mártir Pedro de Verona; a su izquierda, las terciarias Catalina de Siena y Rosa de Lima (canonizada en I671) y la monja Inés de Monte Pulciano, beatificada en 1608 y canonizada en 1726 . Es de resaltar el interés de los dominicos por mostrar a los fieles que tres de sus santos "más nuevos" estaban en el cielo dispuestos a ayudar a quienes acudieran a su iglesia. Por su intermediación el manto protector de la Virgen del Rosario cubría desde la cúpula del templo a todos aquellos que entraban a orar en él (fig. 6).

La imagen de la Virgen de la Misericordia también fue muy difundida en este siglo por los jesuitas. En el sotocoro de la iglesia de San Francisco Javier, anexa al noviciado de Tepotzotlán, Miguel Cabrera pintó una composición que representa a la Virgen María como una "Asunción”, con Jesús Niño en su brazo y sostenida por una nube con angelillos. Los miembros de la Compañía, situados bajo su manto, están divididos en dos grupos encabezados cada uno de ellos por el fundador de la orden, Ignacio de Loyola, y por Francisco Javier, patrono de las misiones y santo al que está dedicado el templo. El enorme manto azul es sostenido por los arcángeles Miguel y Gabriel y por otros dos angelillos en actitud de arrojar ramos de azucenas, asociadas con la pureza y la castidad, sobre los jesuitas. La escena está coronada por Dios Padre y el Espíritu Santo. ${ }^{23}$ Frente a este cuadro se encuentra otro del mismo autor con un Cristo que derrama su sangre sobre las ánimas del Purgatorio. Tenemos ahí

22. Trens, María. Iconografía de la Virgen en el arte español, 282.

23. Pablo de Gante, Tepotzotlán, su historia y sus tesoros artísticos (Ciudad de México: 


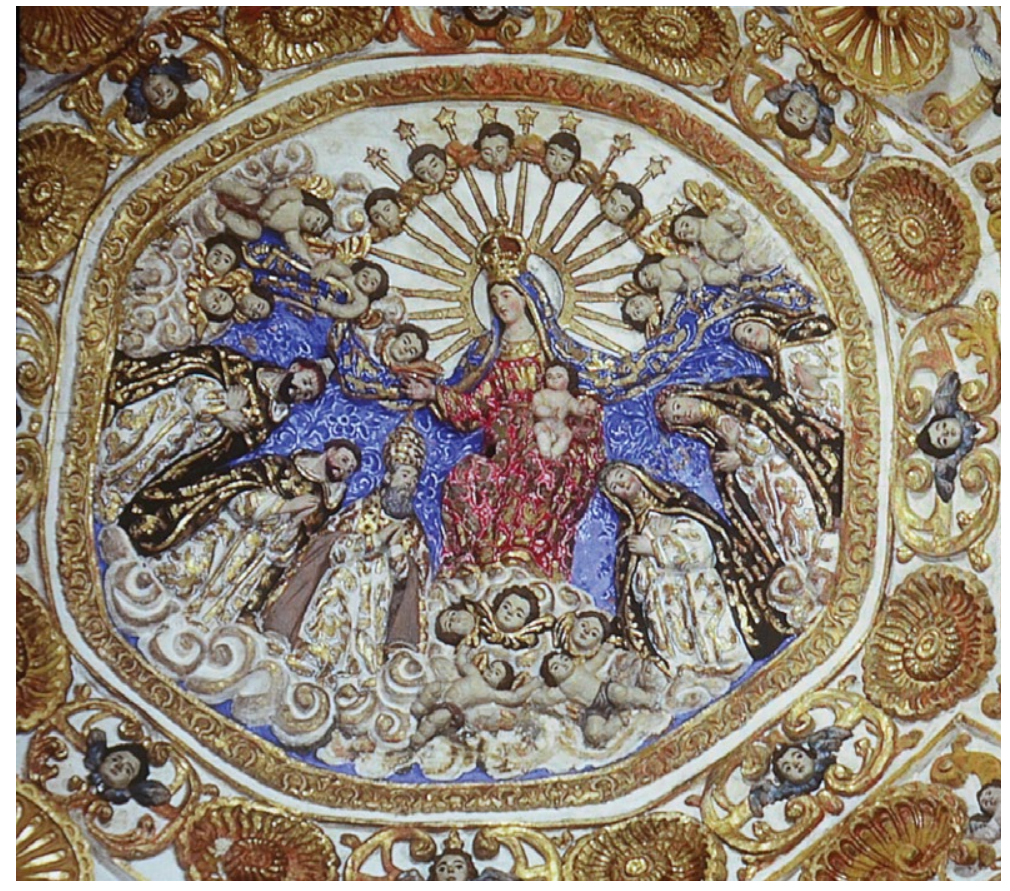

6. Anónimo, Relieve de estuco policromado del patrocinio de la Virgen del Rosario con santos dominicos, iglesia de Santo Domingo, Oaxaca. Foto del autor. Secretaría de Cultura INAH-Méx. "Reproducción autorizada por el Instituto Nacional de Antropología e Historia”.

un claro ejemplo de cómo un mensaje de patrocinio sobre la orden que administra la iglesia dialoga, en un mismo espacio (el sotocoro), con otro que también implica "protección", pero ahora sobre los laicos que purgan sus culpas, deudos de los usuarios del templo (fig. 7).

Entre los franciscanos las imágenes marianas centraron su interés en el culto a la Inmaculada Concepción, devoción difundida por la orden desde el siglo XIII por el teólogo Juan Duns Scoto, promovida en el siglo XV por el pontífice de la orden Sixto IV, tras una enconada polémica entre franciscanos y dominicos sobre si María había sido concebida con o sin el pecado original.

Porrúa, 1958), 179. Véase una buena reproducción del lienzo en www.mediateca.inah.gob. mx.pintura:2I4I. 


\section{DOI: https://doi.org/10.22201/iie.18703062e.2021.119.2760}

\section{I92 ANTONIO RUBIAL GARCÍA}

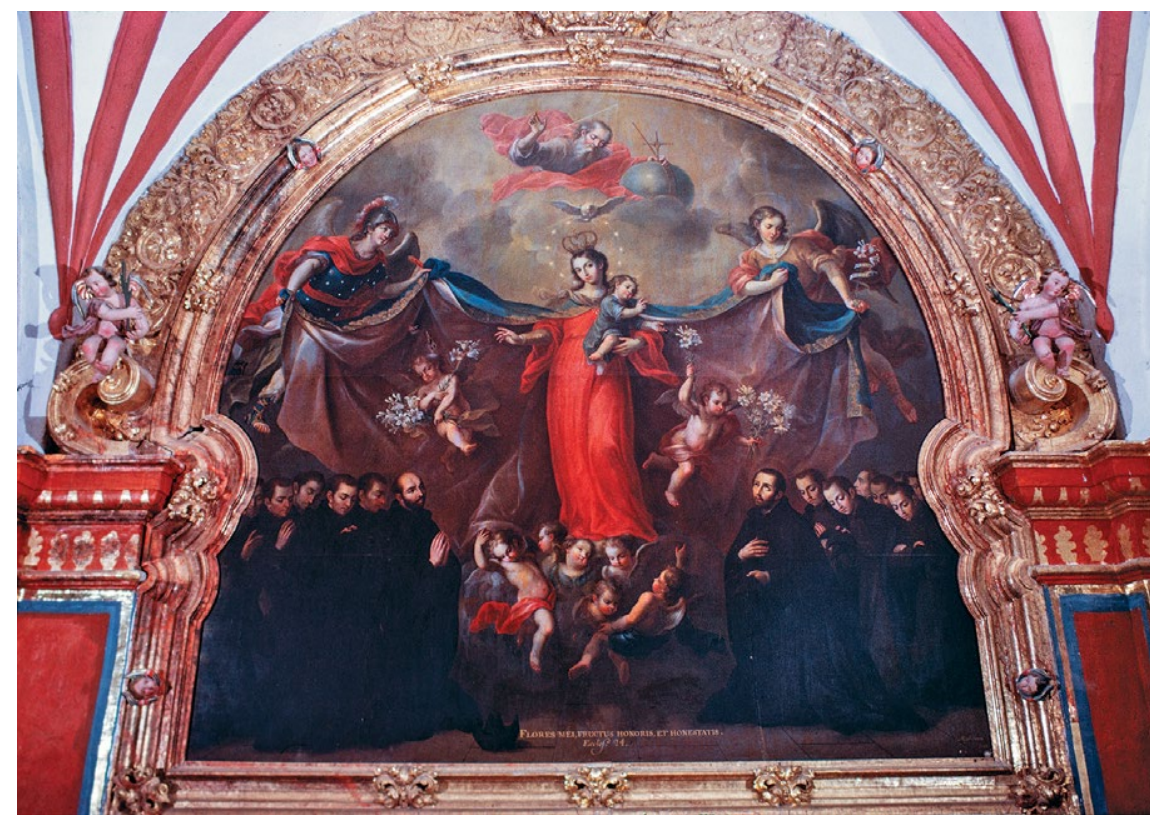

7. Miguel Cabrera, Patrocinio de la Virgen de la Asunción sobre la Compañía de Jesús, templo de San Francisco Xavier, Tepozotlán, Estado de México. Archivo Fotográfico "Manuel Toussaint”, Instituto de Investigaciones Estéticas, UNAM.

A partir del xviI, con el impulso del rey español Felipe III, la Inmaculada fue jurada patrona del imperio en I6I2. Su sucesor Felipe IV, influido por la monja concepcionista sor María de Agreda, le dio un nuevo estímulo al culto y, junto con los emperadores de la rama alemana de los Habsburgo, la Inmaculada se volvió un tema central de la Pietas Austriaca. ${ }^{24}$

24. El culto inmaculista despertó fuertes polémicas entre los dominicos (que negaban su validez) y los franciscanos que lo promovían. A estas discusiones se unieron los jesuitas, sobre todo Francisco Suárez y Pedro Canisio, quienes apoyaron la postura franciscana, con lo cual la posición maculista dominicana se radicalizó, al igual que sus confrontaciones con la Compañía. Finalmente, el 8 de diciembre de I66I, el papa Alejandro VII zanjaba la disputa al emitir una constitución pontificia en la cual definió el verdadero sentido de la palabra conceptio, y prohibió toda ulterior discusión. Véase al respecto el estudio de Anna Coreth, Pietas Austriaca. Austrian Religious Practices in the Baroque Era (Indiana: Purdue University Press/ West Lafayette, 2004). 
En la Nueva España, la gran fuerza del culto inmaculista coincidió con la promoción, iniciada en el cabildo de la catedral metropolitana y avalada por varios arzobispos, de la advocación a la Virgen de Guadalupe, una representación con rasgos indígenas de la Inmaculada Concepción. Esta imagen sirvió como centro de uno de los cuadros de "patrocinio" del siglo xviII más impresionantes, obra probable del pintor oaxaqueño Miguel Cabrera. ${ }^{25}$ El lienzo se encuentra en el cubo de la escalera principal del colegio de Propaganda Fide de Zacatecas, dedicado por su fundador, fray Antonio Margil de Jesús, a la advocación guadalupana y cuya ocupación principal eran las misiones entre los pueblos nómadas y la predicación a los fieles en las villas y ciudades del virreinato. A pesar de su independencia del resto de las provincias franciscanas, dicho colegio tenía a san Francisco como su padre fundador y, de hecho, este santo es el que porta el enorme manto marrón sostenido por angelillos bajo el cual aparece la comunidad de frailes, encabezada por el mismo fundador del colegio fray Antonio Margil, cuyo proceso de beatificación se llevaba en Roma por entonces.

San Francisco porta sobre sus hombros la imagen de la Virgen de Guadalupe, la titular del instituto, siguiendo un modelo iconográfico instaurado por Pedro Pablo Rubens conocido como Seraphicus Atlas. En la obra del pintor flamenco, difundida gracias al grabado que de ella realizó Paulus Pontius entre I631 y I632, el santo de Asís porta sobre sus hombros a la Inmaculada quien se yergue sobre las tres esferas que simbolizan las órdenes por él fundadas. ${ }^{26} \mathrm{En}$ la pintura de Zacatecas, la Guadalupana ha sustituido a la Inmaculada, se han eliminado las esferas y se ha colocado en el cielo a la Santísima Trinidad flanqueada por san José y san Miguel arcángel (fig. 8).

25. El cuadro no está firmado y la autoría de Cabrera está siendo hoy cuestionada por algunos especialistas. Comunicación personal con Paula Mues Orts, 7 de octubre de 2020. 26. Posiblemente este grabado estaba destinado a ilustrar uno de los muchos tratados que defendían la Inmaculada Concepción. Al lado izquierdo del Seraphicus Atlas y de la Inmaculada, cuatro franciscanos (uno de ellos Duns Scoto) empujan con sus lanzas a la herejía dentro de las fauces del Infierno. A la derecha están representados Felipe IV y sus hermanos, el Cardenal Infante Fernando, don Carlos y el príncipe Baltasar Carlos. En el cielo, sobre un carro tirado por cuatro águilas, se encuentran los antepasados de Felipe IV, Carlos V, Felipe II y Felipe III. Frente a ellos, otro carro jalado por leones porta a las cuatro virtudes cardinales propias del buen gobernante: templanza, fortaleza, prudencia y justicia. La imagen ilustraría así la defensa de la Inmaculada Concepción por parte de los Habsburgo españoles y de sus aliados los franciscanos. Véase Suzanne Stratton-Pruitt, La Inmaculada Concepción en el arte español (Madrid: Fundación Universitaria Española, 1989), 74. 
DOI: https://doi.org/10.22201/iie.18703062e.2021.119.2760

I94 ANTONIO RUBIAL GARCÍA

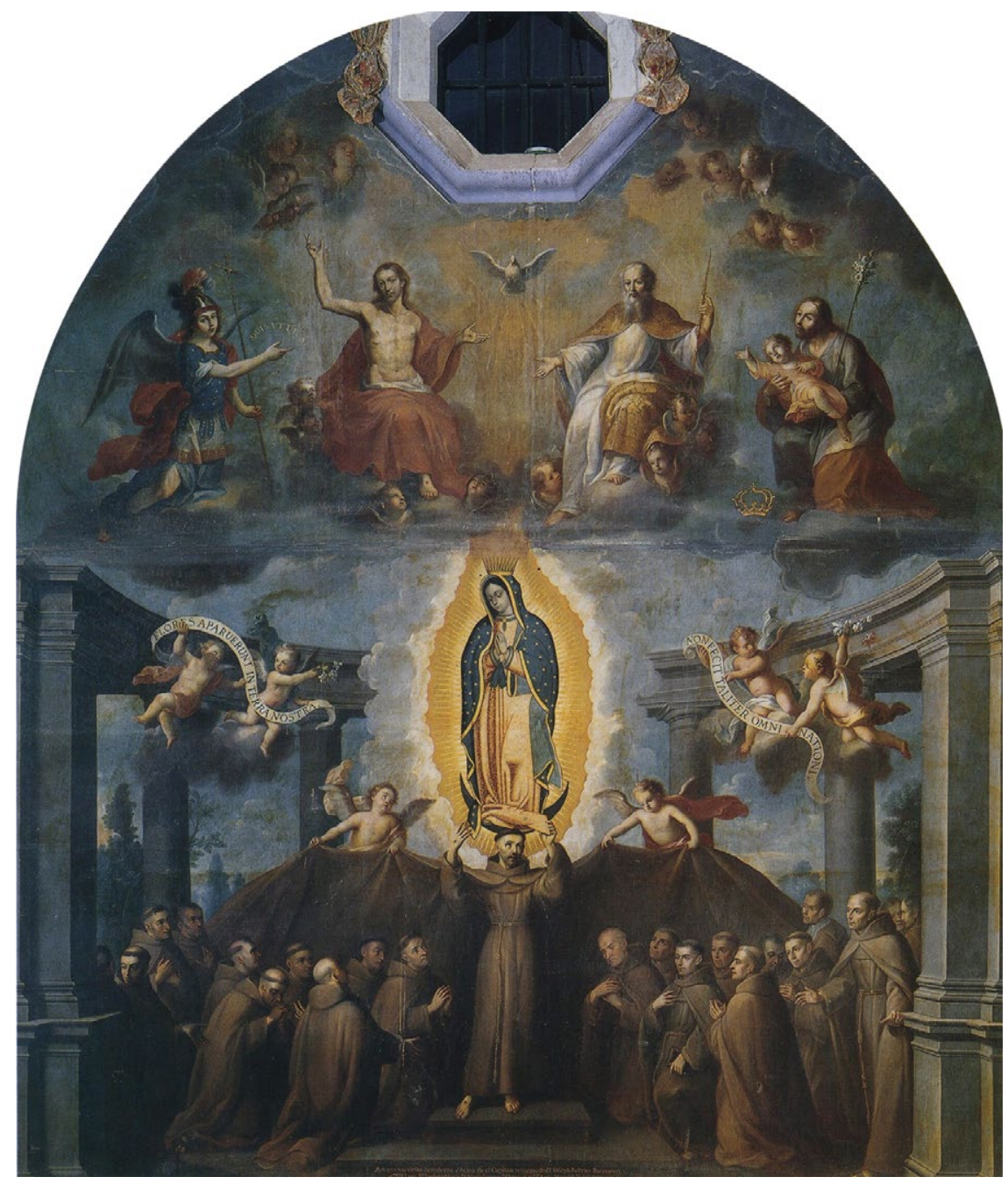

8. Miguel Cabrera (atribución cuestionada), Patrocinio de san Francisco y la Virgen de Guadalupe, Museo del ex colegio franciscano de Propaganda Fide de Guadalupe, Zacatecas. Tomada de Federico Sescosse, El Colegio de Guadalupe de Zacatecas: escuela de misioneros y semillero de martires, I706-I993 (Ciudad de México: Multiva Grupo Financiero/Fondo Cultural Bancen, I993), 7I. 


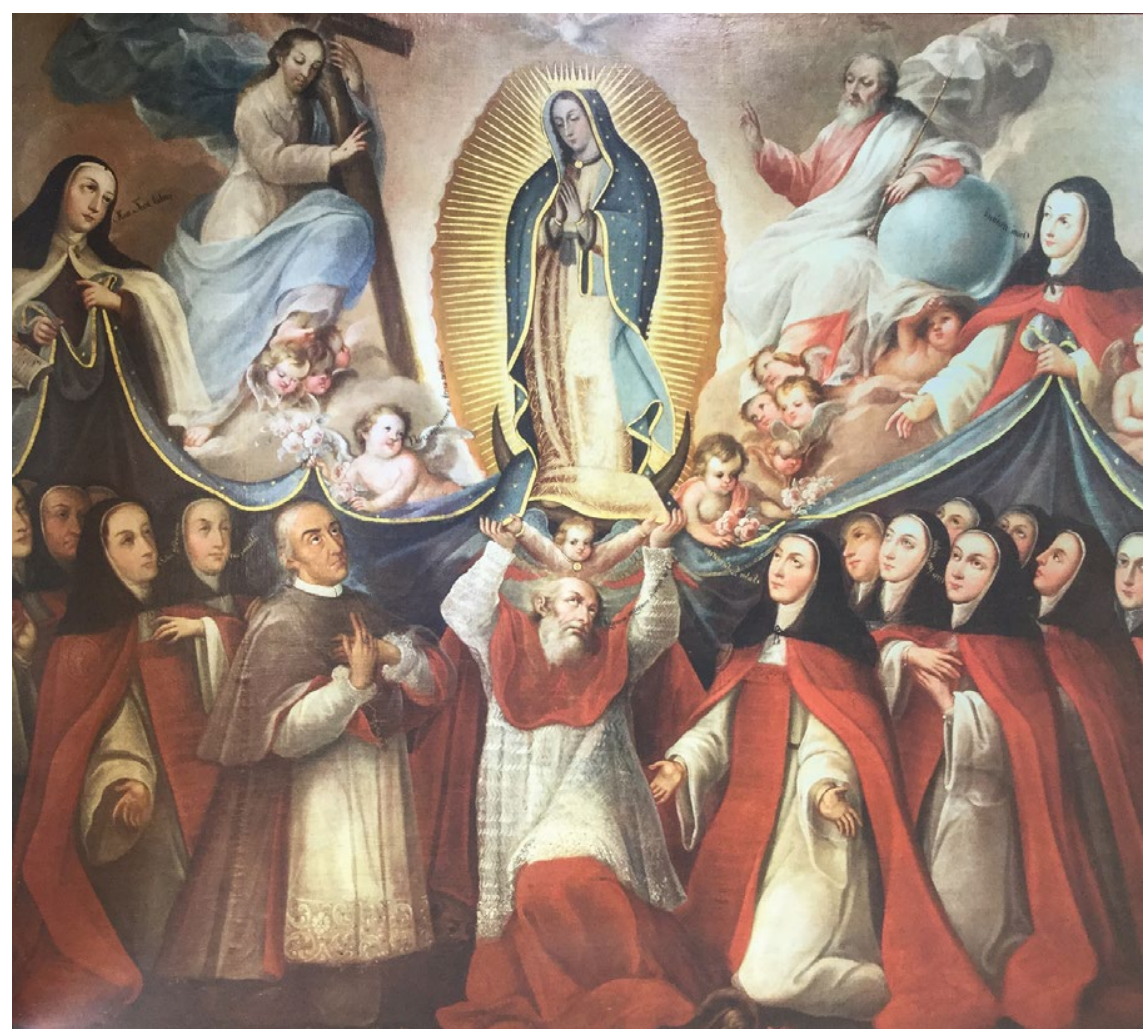

9. José Joaquín Magón, La Virgen de Guadalupe y san Jerónimo protegen a la comunidad de religiosas jerónimas y al obispo Pantaleón Álvarez Abreu, Museo Exconvento de Santa Mónica, Puebla. Tomada de Alejandro Andrade Campos, El pincel de Elias. José Joaquin Magón y la orden de Nuestra Señora del Carmen (Puebla: Benemérita Universidad Autónoma de Puebla, 2015), 79.

El renovado modelo tuvo un relativo éxito y fue imitado por José Joaquín Magón en Puebla en una pintura para el monasterio de las monjas jerónimas, actualmente colocado en el repositorio del museo exconvento de Santa Mónica. En el centro del cuadro un san Jerónimo, vestido con un hábito color carmesí cubierto por un sobrepelliz, sostiene a una Virgen de Guadalupe cuyo manto se extiende sobre la comunidad de las religiosas vestidas con sus hábitos rojos y blancos y acompañadas de su "padre terrenal", el obispo de Puebla, Domingo Pantaleón Álvarez de Abreu. Junto a dos angelillos que reparten flores, y bajo la mirada de la Santísima Trinidad, el gran manto de la Virgen es 


\section{DOI: https://doi.org/10.22201/iie.18703062e.2021.119.2760}

196

ANTONIO RUBIAL GARCÍA

sostenido por santa Teresa de Ávila y santa Paula de Roma, la mítica fundadora de la rama femenina de la orden. Alejandro Andrade, quien ha estudiado este cuadro, aventura la idea de que pudo haber sido un exvoto por la curación de la comunidad jerónima de una epidemia. ${ }^{27}$ La presencia en este cuadro del obispo Álvarez de Abreu, mecenas y promotor de muchas obras en la diócesis de Puebla, es un signo del poder que había conseguido el episcopado dieciochesco con el apoyo de la Corona (fig. 9).

La consolidación de las episcópolis y del clero secular. El triunfo de la Inmaculada Concepción en los patrocinios ${ }^{28}$

Entre los siglos XVI y XVIII el episcopado americano vivió un proceso de consolidación que afectó tanto a los territorios de sus diócesis como a las capitales en las que los obispos y sus cabildos tenían sus sedes. Al tiempo que se afianzaban los mecanismos de control sobre las doctrinas en manos de los regulares, se fortalecían varias instituciones en las sedes episcopales dirigidas a reforzar su presencia y la de sus capitulares: provisoratos que administraban la justicia eclesiástica; juzgados de testamentos y capellanías para mejorar la administración de los ingresos del clero; seminarios conciliares para la preparación de una élite clerical; hospitales, orfanatos, residencias estudiantiles y recogimientos para mujeres para reforzar la imagen caritativa episcopal; cofradías y congregaciones que fomentaban las actividades religiosas entre laicos y clérigos. Los obispos también financiaron la impresión de obras teológicas, jurídicas y devocionales, de manuales para la administración de los sacramentos y de cartas pastorales que trataban temas de orden práctico y moral.

La presencia episcopal en los cuadros de patrocinio se generalizó en una época en la que el regalismo borbónico había dado a los obispos su total apoyo frente a las órdenes religiosas. Aunque en su origen había sido una promoción franciscana, la Inmaculada Concepción se volvió abanderada de los intereses obispales y catedralicios y uno de los cultos más impulsados por la dinastía borbónica. En I76r el rey Carlos III la juró como patrona universal de los reinos de Espańa y las Indias.

27. Andrade, El pincel de Elías, 78-79.

28. Tomo el término "episcópolis" de Fernando de la Flor, Barroco. Representación e ideología en el mundo hispánico (I580-I680) (Madrid: Cátedra, 2002), I48. 
Uno de los ejemplos más interesantes de esta apropiación del culto por parte de las catedrales es el cuadro que representa el patrocinio de la Inmaculada Concepción sobre el episcopado y el cabildo eclesiástico de Puebla. El gran lienzo fue pintado por Luis Berrueco alrededor de 1750 para conmemorar las obras realizadas en el templo por el obispo Domingo Pantaleón Álvarez Abreu. ${ }^{29}$ Situado en la sacristía, aparecen en él seis santos sosteniendo el manto protector de la Virgen: dos de ellos son los patronos de la ciudad, san Miguel y san José; otros dos, los titulares del clero secular, san Pedro y san Pablo; la monarquía y el imperio están representados por el apóstol Santiago; y América, por la única santa criolla canonizada, Rosa de Lima. Bajo el manto se retrataron el propio obispo Álvarez Abreu y los 24 miembros de su cabildo, mecenas de la obra, acompañados por angelitos con cartelas que contienen frases de la letanía mariana. En el centro de estos "protegidos", dos obispos "históricos" muestran la sólida tradición episcopal poblana, fray Julián Garcés, fundador de la sede y Juan de Palafox, quien concluyó la catedral.

Para el siglo XviII, este último prelado se había convertido para la Nueva España en el prototipo del obispo ideal, caritativo, reformador, letrado y virtuoso; pero al mismo tiempo también era el modelo para los obispos borbónicos, defensores de los privilegios de la monarquía sobre la Iglesia, jefes indiscutibles del clero secular y promotores de la secularización de las parroquias de los regulares. ${ }^{30}$ La episcópolis poblana conmemoraba con este cuadro una larga trayectoria y la presencia en él de Juan de Palafox, cuyo proceso de beatificación se llevaba en Roma en ese momento, avalaba una historia iniciada en el siglo XVI, reforzada en el XVII y consumada en el XVIII (fig. Io).

29. Hay una muy buena reproducción en la revista Artes de México, núm. 40 (1998): 26. Para su descripción y análisis se puede consultar el excelente estudio de Claudia Cristell Marín Bertollini, "El patrocinio de la Inmaculada Concepción sobre el cabildo angelopolitano. La imagen al servicio del poder", en Pinceles y gubias del Barroco iberoamericano, María de los Ángeles Fernández, Carme López e Inmaculada Rodríguez, coords., vol. 7 (Santiago de Compostela y Sevilla: Universidad Pablo Olavide y Andavira Editora, 2019), II9-I36. Consultado en www.upo.es/investiga/enredars/?page_id=I4I5. La autora no sólo incluye la última documentación sobre su atribución al pincel de Berrueco, sino también las relaciones simbólicas del cuadro con las otras pinturas de la sacristía.

30. Antonio Rubial García, "El rostro de las mil facetas. La iconografía palafoxiana en Nueva España”, en Juan de Palafox y Mendoza. Imagen y discurso de la cultura novohispana, José Pascual Buxó, coord., Estudios de Cultura Literaria Novohispana, I8 (Ciudad de México: Universidad Nacional Autónoma de México-Instituto de Investigaciones Bibliográficas, 2002), 300-324. 
DOI: https://doi.org/10.22201/iie.18703062e.2021.119.2760

198

ANTONIO RUBIAL GARCÍA

Io. Luis Berrueco, Patrocinio de la Inmaculada Concepción sobre los obispos y el cabildo de la catedral angelopolitana. Sacristía de la Catedral de Puebla. Foto: Héctor Crispín González. Cortesía de Claudia Cristell Marín Berttolini.

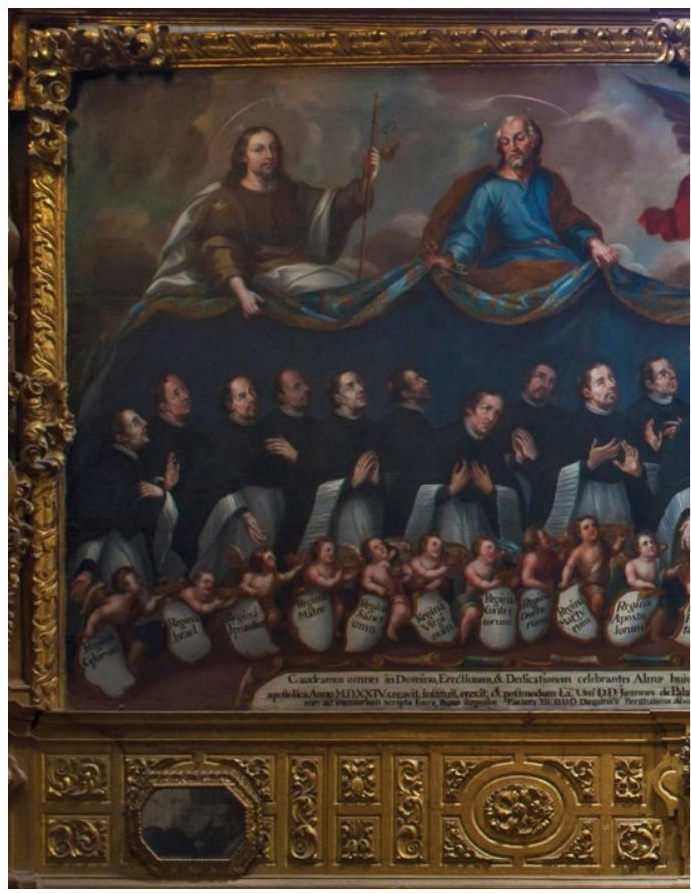

El cuadro de Berrueco es especialmente notable también por la fidelidad con que se representan los rostros de los obispos Palafox y Álvarez de Abreu, y quizá también los de los capitulares. Frente a las obras de "patrocinio" de los siglos anteriores, en las cuales los "protegidos" no mostraban rasgos individualizados, en varios de los personajes pintados en las del XVIII en estos cuadros estamos ante verdaderos retratos. Esta característica se vuelve más notable en las últimas décadas de dicha centuria, lo que coincide además con el inusitado éxito que tuvieron los patrocinios del patriarca san José tanto en las catedrales como en otros ámbitos clericales e incluso entre la nobleza indígena.

\section{Los patrocinios del Señor san José y de la Virgen María como discursos politicos}

El culto a san José tuvo un gran desarrollo en la Nueva España desde el siglo XVI. En el primer concilio provincial mexicano de I555, el episcopado había 


\section{DOI: https://doi.org/10.22201/iie.18703062e.2021.119.2760}

TIPOLOGÍA ICONOGRÁFICA DE LA VIRGEN DE LA MISERICORDIA

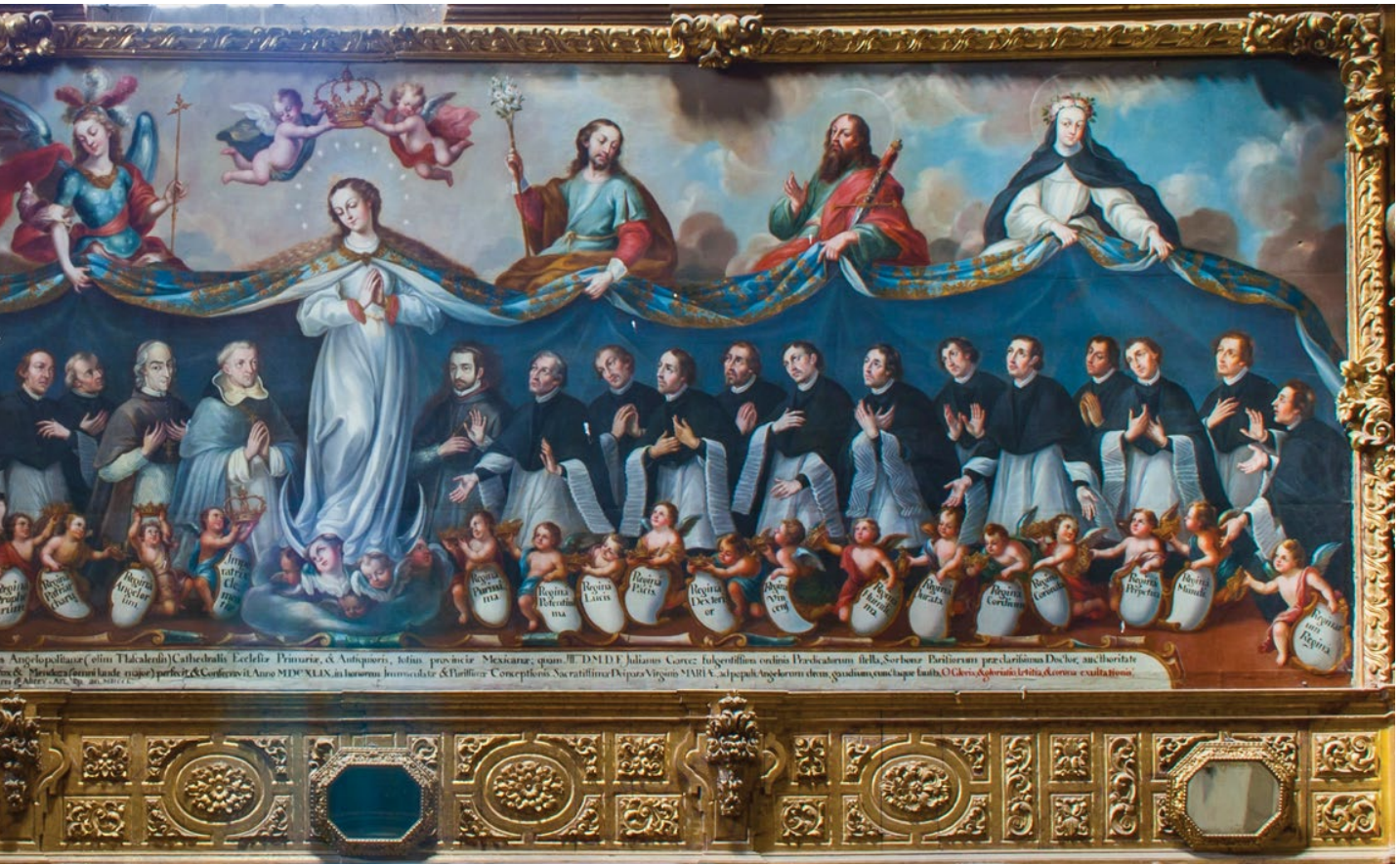

proclamado al padre putativo de Cristo como patrono y abogado de la Iglesia novohispana, patronato ratificado en el tercer concilio de 1585 . Pero los obispos no fueron los únicos en promocionarlo; antes que ellos los franciscanos y después los carmelitas descalzos (por ser devoción de santa Teresa) lo tenían como una de sus principales advocaciones. Los ayuntamientos de varias ciudades, como Puebla y México, lo juraron como su patrono contra rayos y tempestades. A lo largo del siglo xviı, como lo ha señalado Jaime Cuadriello, en varias de sus representaciones se le asoció con el bíblico José, el virrey de Egipto, se le comenzó a representar con una corona y se le consideró un cuasi rey de la Nueva España. ${ }^{3 \mathrm{I}}$

La efímera jura que el rey Carlos II hizo en I678, poniendo a san José como patrono de sus dominios, y la impugnación a dicho patronato por parte de la catedral de Santiago de Compostela, debió afianzar aún más la

3I. Jaime Cuadriello, "San José en tierra de gentiles: ministro de Egipto y virrey de las Indias", Memoria, Revista del Museo Nacional de Arte, núm. I (otońo-invierno 1989): 5-56. 


\section{DOI: https://doi.org/10.22201/iie.18703062e.2021.119.2760}

vinculación del Patriarca con la Nueva España, en cuyo territorio se hizo caso omiso de la impugnación compostelana y donde san José siguió siendo visto como patrono del imperio. Esto favoreció que en el siglo XVIII se popularizaran las imágenes que representaban su patrocinio $\mathrm{y}$, a partir de la segunda mitad de la centuria, lo mostraron a menudo coronado y cubriendo con su manto a las autoridades imperiales, tanto al rey y al papa, como a los máximos funcionarios americanos. ${ }^{32}$

Varios de estos cuadros se encargaron para las catedrales, cuyos cabildos en tiempos de Carlos III se debatían entre la fidelidad a sus obispos ilustrados y al rey y los intereses locales de sus canónigos. Éstos, y en general el clero secular, se habían visto fuertemente golpeados por la creciente interferencia del rey en la administración de los diezmos, por las demandas constantes del llamado subsidio eclesiástico ${ }^{33} \mathrm{y}$ por las amplias prerrogativas sobre las iglesias españolas y americanas que, bajo presiones políticas, el pontífice había concedido a la Corona borbónica en tres concordatos, el de 1717, el de 1737 y, sobre todo el de 1753. Gracias a ellos, los monarcas recibieron el dominio absoluto sobre las iglesias hispánicas y el control total de sus nombramientos eclesiásticos. Con los concordatos se consolidaba un régimen, el regalismo, que veía dichos privilegios como algo inherente al ejercicio de la soberanía del monarca y no como concesiones pontificias.

En este contexto se pintaron tres cuadros que tenían el patrocinio del patriarca como tema y que fueron promovidos por los obispos borbónicos. El primero, realizado para la catedral de Mérida en Yucatán en I783, está vinculado con un conflicto local entre las autoridades civil y religiosa. En él se representa al patriarca cobijando al obispo benedictino fray Luis Pińa y Mazo y al gobernador Joseph Merino, quienes presiden a cuatro personajes anónimos que simbolizan al clero yucateco (un fraile y un cura) y a dos laicos españoles.

32. Antes que lo hiciera Carlos II para el imperio español, ya habían jurado a san José como protector el emperador austriaco Fernando III durante la Guerra de 30 años (I648) y Leopoldo I cuando aún era regente durante el sitio de Viena por los turcos en I683. Agradezco a Jorge Luis Merlo Solorio esta nota.

33. El subsidio era una contribución directa de 6 por ciento sobre los ingresos del clero, fueran comunidades o individuos del clero secular o regular. Sobre este tema véase el estudio de Rodolfo Aguirre Salvador, Un clero en transición. Población clerical, cambio parroquial y política eclesiástica en el arzobispado de México (I700-I750) (Ciudad de México: Universidad Nacional Autónoma de México-Instituto de Investigaciones sobre la Universidad y la Educación, 20I2), 285-318. 
Realizado con motivo del arribo del nuevo gobernador, después de unas conflictivas relaciones del obispo con el funcionario anterior, muestra las expectativas de la mitra para que ambos poderes funcionen de manera armónica bajo la mirada del ministerio celestial de san José. El acuerdo no duró mucho pues ambas autoridades volvieron a enfrentarse unos meses después. ${ }^{34}$

En otros dos lienzos relacionados con las catedrales se mostraban, con un ambiguo discurso, al rey Carlos III y al papa Pío VI, representados en un mismo nivel y sumisión. En el Museo Regional de Morelia hay un san José en su advocación de "refugio de los agonizantes", bajo cuyo manto se colocó al rey y al Papa y, junto a ellos, al obispo Juan Ignacio de la Rocha, quien gobernó la diócesis michoacana entre 1777 y 1782 y muy posiblemente estuvo implicado en su factura. ${ }^{35}$

Con tema similar, y retratando a las mismas autoridades imperial y pontificia, Miguel Jerónimo Zendejas pintó un cuadro para la capilla de las reliquias de la catedral de Puebla en I786, ańo calamitoso por la escasez de alimentos provocada por la pérdida de las cosechas a consecuencia de las heladas. A san José se le representa coronado, cargando al niño Jesús con una cruz en los brazos, rodeado de los ángeles protectores de Puebla y bajo la mirada del Padre Eterno y del Espíritu Santo. El obispo Victoriano López Gonzalo, quien aparece retratado detrás del papa Pío VI, tuvo una especial actividad caritativa durante la crisis agrícola y el cuadro dedicado a san José debió ser promovido por él como parte de su proyección como "padre de los pobres". Detrás del obispo están un canónigo y un párroco en representación de la catedral y del clero secular. En el extremo opuesto al grupo eclesiástico, Carlos III ofrece su cetro y corona al Patriarca, seguido del virey Bernardo de Gálvez, de un indígena que porta en su mano un corazón y del recién llegado intendente de Puebla, Manuel Flon.

En los tres cuadros es muy explícito el mensaje de sujeción a las autoridades, tanto terrenas como celestiales, ambas representadas con un mismo sentido de protección. Ésta se ve especialmente remarcada en el caso del "patrocinio" poblano, estudiado por Alejandro Andrade, pues tanto el obispo López como el virrey Gálvez estaban tomando medidas para paliar los efectos de la crisis.

34. Víctor Hugo Medina Suárez, "Cuadro del patrocinio de San José. Conflictos jurisdiccionales entre el obispo y el gobernador (Yucatán 1780-I795)”, Temas Antropológicos. Revista de Investigaciones Regionales 40, núm. 2 (abril-septiembre de 20I8): I-I5.

35. Corvera, "El patrocinio. Interpretaciones sobre una manifestación artística novohispana”, 136. 


\section{DOI: https://doi.org/10.22201/iie.18703062e.2021.119.2760}
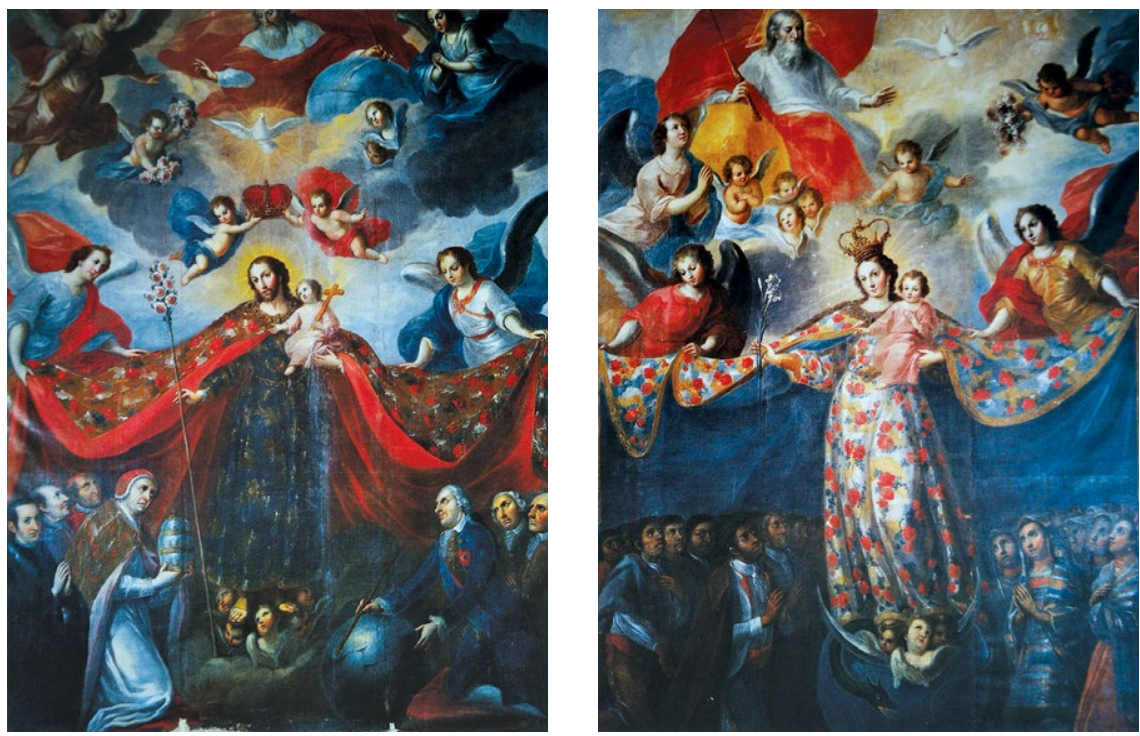

II. Miguel Jerónimo Zendejas, Patrocinios de san José y la Virgen sobre las autoridades civiles y eclesiásticas y los indios, parroquia de Tamazulapan, Oaxaca, 1754. Tomado de Vargas Lugo, coord., Imágenes de los naturales en el arte de la Nueva España. Siglos XVI al XVIII (vid infra n. 37), 264.

Por otro lado, la presencia de un indio en el lienzo de Zendejas hace patente que los "naturales" fueron la población más abatida por el hambre, pero también que, a pesar de las circunstancias debían seguir fieles a sus autoridades. ${ }^{36}$

Esa necesidad de mostrar sujeción al patrocinio celestial y terrenal se hizo presente también en las comunidades indígenas, donde las imágenes de san José como protector se multiplicaron a partir de la segunda mitad del XviII y en varias de ellas el monarca y el pontífice fueron representados como garantes de dicha protección. Son especialmente notables dos que se encuentran en el templo parroquial de Tamazulapan (Oaxaca), firmados también por Miguel Jerónimo Zendejas y fechados en I754, el mismo año en que la parroquia dominica fue entregada al clero secular. El lienzo del patrocinio de san José sobre Fernando VI

36. Alejandro Andrade Campos, "José patriarca universal. Uso y función de las representaciones josefinas en la Puebla de la segunda mitad del siglo XviII", tesis de maestría en Historia del Arte (Ciudad de México: Universidad Nacional Autónoma de México-Facultad de Filosofía y Letras, 20I6), 85-91. Ésta se puede consultar en www.tesis.unam.mx. 


\section{DOI: https://doi.org/10.22201/iie.18703062e.2021.119.2760}

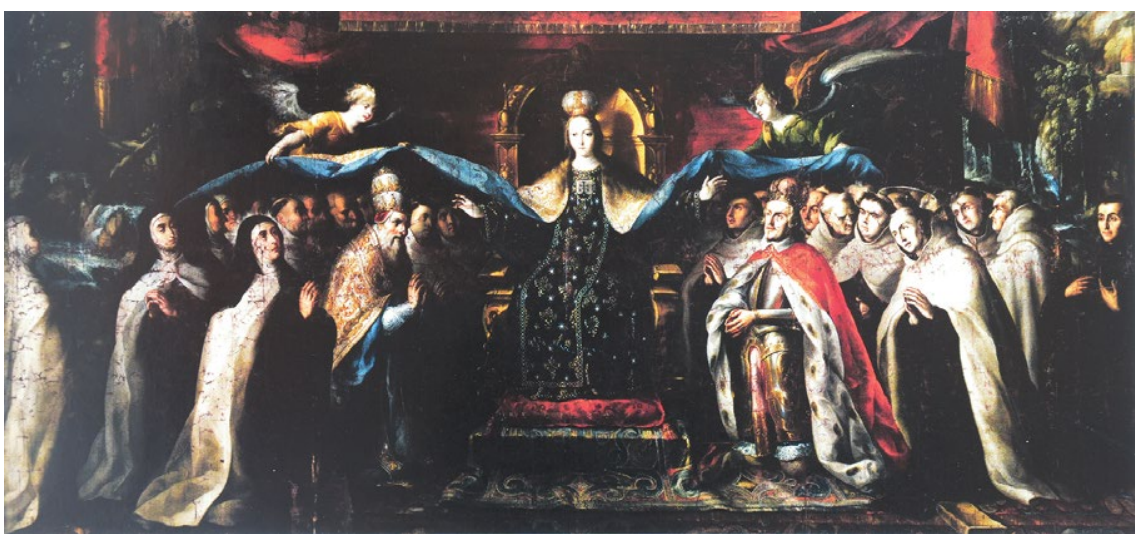

I2. Juan Rodríguez Juárez, La Virgen del Carmen como Sedes Sapientiae protege al emperador, al pontifice y a su orden. Sacristía del templo del Carmen Viejo, Centro Histórico, Ciudad de México. Tomada de Ilona Katzew, Jaime Cuadriello, Paula Mues y Luisa Elena Alcalá, Pintado en México (I700-1790). Pixit Mexici (Ciudad de México y Los Ángeles: Fomento Cultural Banamex/ Los Angeles Country Museum of Art, 2017), II7.

y Benedicto XIV y las autoridades espańolas, de formato muy similar al de la catedral de Puebla que fue pintado 32 años después, comparte el espacio con otro que representa a la Virgen con el Nińo Jesús protegiendo bajo su manto a hombres y mujeres de la comunidad indígena. Es significativo que en ambos cuadros las imágenes celestiales estén coronadas, lo que reafirma la necesidad de sujeción a la monarquía hispana, reinante "por la gracia de Dios" (fig. II). ${ }^{37}$

Los cuadros de Tamazulapan muestran también que el modelo de los patrocinios josefinos protegiendo a las autoridades no era exclusivo de este patriarca, y que otras representaciones ya habían colocado a María en un papel similar. Uno de los ejemplos más tempranos a este respecto es una Virgen del Carmen en la sacristía del templo que esta orden tenía en el barrio de San Sebastián de la Ciudad de México. El cuadro está fechado en 1708, firmado por Juan Rodríguez Juárez y muestra a dicha advocación mayestática, sentada en un trono, sin el niño, como Sedes Sapientiae. Bajo un manto sostenido por dos ángeles, frailes y monjas carmelitas encabezados respectivamente por san Juan de la Cruz y

37. Elisa Vargas Lugo, coord., Imágenes de los naturales en el arte de la Nueva España. Siglos XVI al XVIII (Ciudad de México: Fomento Cultural Banamex/Universidad Nacional Autónoma de México- Instituto de Investigaciones Estéticas/Dirección General de Personal, 2005), 264 y 267. 


\section{DOI: https://doi.org/10.22201/iie.18703062e.2021.119.2760}

204

ANTONIO RUBIAL GARCÍA

santa Teresa comparten la protección con un emperador y un pontífice "genéricos", símbolos de las máximas autoridades de la cristiandad, pero que no representan ni a Felipe V ni a Clemente XI. Jaime Cuadriello ha estudiado este cuadro en el contexto de la guerra de sucesión de Espańa, pintado en plena lucha entre el archiduque Carlos de Austria y Felipe de Borbón, al tiempo que llegaba a América la noticia del nacimiento del hijo de este último, el príncipe Luis Fernando (nombres de los dos reyes santos y primos) y con un pontífice que simpatizaba con la causa austriaca. El provincial carmelita recién electo (y retratado en el lienzo) quiso mostrar una "neutralidad acomodaticia", aunque inclinada hacia los borbones, tras la condena de varios carmelitas poblanos que conspiraban a favor del archiduque Carlos de Austria (fig. I2). $3^{8}$

Aunque excepcional y en un contexto distinto, es notable también el cuadro que se encuentra en el santuario tlaxcalteca de San Miguel del Milagro, en el cual se muestra al arcángel cobijando bajo su manto a un pontífice y a un joven rey (quizá Fernando VI) quien encabeza a un numeroso grupo de indios, la mayoría macehuales, cuya vestimenta denota su condición social y cuya presencia, excepcional en este tipo de representaciones, habla del origen de la mayoría de los peregrinos que asistían al santuario que contiene dicha imagen. ${ }^{39}$

Junto con las catedrales, los carmelitas y los pueblos indígenas, los jesuitas representaron también con intenciones "políticas" a las autoridades bajo el manto protector de la Virgen o de san José. Un ejemplo de este modelo apareció en el ámbito de la Compañía en 1735 en un gran lienzo pintado por José de Ibarra para el templo de su colegio noviciado en Tepotzotlán consagrado a san Francisco Javier. La imagen se encuentra en una de sus capillas, la dedicada a san José, que fue inaugurada en 1738 a expensas del escribano mayor de la Real Hacienda, Diego Ruiz Aragonés, y que resguardaba como reliquia un pedazo del manto del patriarca. En el cuadro semicircular, colocado al final de la bóveda enfrente del altar mayor, fueron representados bajo el manto protector del santo patriarca el rey Felipe V y el papa Clemente XII, con sus séquitos de nobles el primero (incluido el donante Ruiz Aragonés), y de los jesuitas, el segundo. El carácter monárquico del mensaje se reafirmaba con la corona que san José está recibiendo de manos de Cristo y de María.

38. Un análisis minucioso de dicho cuadro en Cuadriello, "Politización y sociabilidad de la imagen pública”, II6-II8.

39. Vargas Lugo, Imágenes de los naturales en el arte de la Nueva España, 365 y 366. 


\section{DOI: https://doi.org/10.22201/iie.18703062e.2021.119.2760}

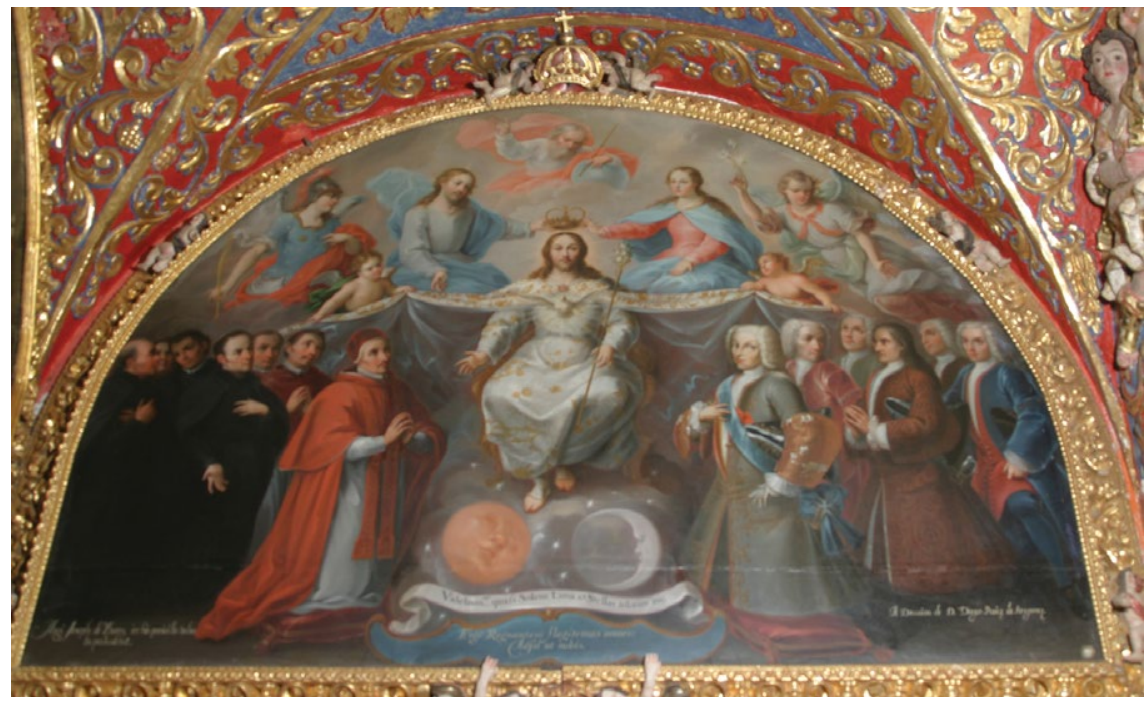

I3. José de Ibarra, Patrocinio de san José sobre las autoridades y los jesuitas, capilla relicario de San José, templo de San Francisco Xavier, Tepozotlán, Estado de México. Tomado de Juana Gutiérrez Haces, coord., La pintura de los reinos. Identidades compartidas. Territorios del mundo hispánico, siglos XVI-XVIII, 4 vols. (Ciudad de México: Fomento Cultural Banamex/Consejo Nacional para la Cultura y las Artes/Museo del Prado, 2008), vol. I, 326.

Al colocar al rey y al papa como pilares de la sociedad y al santo como monarca, se sacralizaba el poder espiritual y temporal que tales figuras simbolizaban, aunque en esos tiempos la relación entre ambos estaba lejos de ser tan armónica como ahí se pintaba. Cuando se estaba dedicando la capilla se acababa de firmar el concordato de i737 entre la monarquía española y la Santa Sede, el cual reforzaba los controles del rey sobre las iglesias de todo el imperio. Por otro lado, la presencia de los jesuitas detrás del Papa no dejaba de ser significativa, dada la defensa a ultranza que la Compañía realizaba de la primacía pontificia (fig. I3)..$^{\circ}$

El último concordato entre el papado y la monarquía hispánica se firmaba, como mencioné arriba, en tiempos del rey Fernando VI en 1753, cuando aún los jesuitas tenían una gran influencia en la corte gracias a los oficios del confesor del rey, Francisco de Rávago, quien participó activamente como su

40. Mues, El pintor novohispano José de Ibarra, vol. I, I87-I89. 


\section{DOI: https://doi.org/10.22201/iie.18703062e.2021.119.2760}

\section{6}

ANTONIO RUBIAL GARCÍA

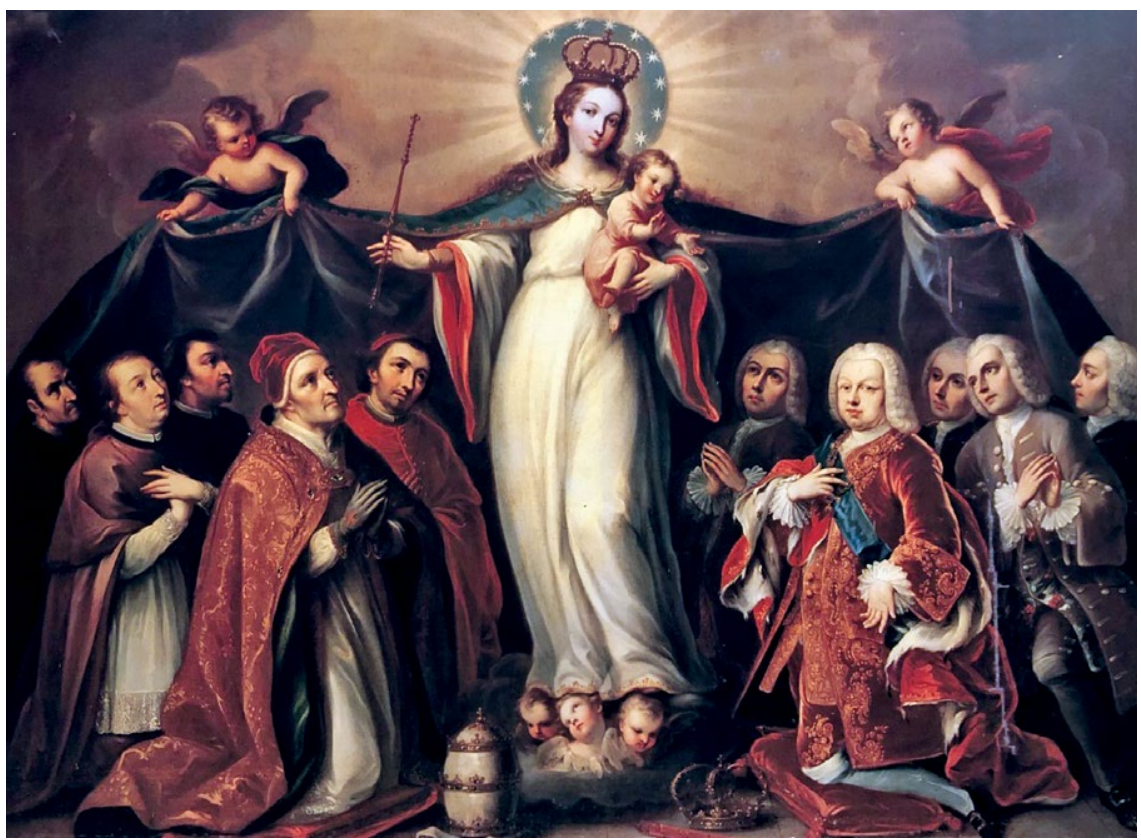

I4. José de Ibarra (atribuido), Patrocinio de la Virgen sobre el rey y el Papa, Pinacoteca de la Profesa, Centro Histórico, Ciudad de México. Tomada de Un privilegio sagrado. La Concepción de María Inmaculada. La celebración del dogma en México (Ciudad de México: Museo de la Basílica de Guadalupe-Apostólico Colegio de Nuestra Señora de Guadalupe, 2006), I47.

representante en la firma del importante acuerdo. ${ }^{4 \mathrm{I}}$ Es muy probable, como sugiere Paula Mues, que a raíz de ese acontecimiento se pintara otro cuadro de patrocinio, pero en esta ocasión no de san José sino de la Virgen con el Niño. Esta obra, atribuida por dicha investigadora a José de Ibarra, está actualmente en la pinacoteca de la casa Profesa de la Ciudad de México y en ella se representan, bajo el manto protector sostenido por dos angelillos, al rey Fernan-

4I. Francisco Iván Escamilla González, "Los confesores reales de España en la época borbónica y su intervención en la política americana de la monarquía: el caso de Francisco de Rávago, S. J., confesor de Fernando VI”, en La dimensión imperial de la Iglesia novohispana. Siglos XVI-XVIII, Pilar Martínez y Francisco Cervantes, coords. (Ciudad de México: Universidad Nacional Autónoma de México-Instituto de Investigaciones Históricas/Benemérita Universidad Autónoma de Puebla-Instituto Alfonso Vélez Pliego, 2016), 225-248. 
do VI, al papa Benedicto XVI, al arzobispo Manuel Rubio y Salinas, a otros dignatarios civiles y eclesiásticos y a dos miembros de la Compañía de Jesús. ${ }^{42}$

Es paradójico que por esos ańos los jesuitas estuvieran sufriendo fuertes ataques por parte de los jansenistas ilustrados, quienes los llevarían a su expulsión de los dominios franceses, portugueses, austriacos y españoles is años más tarde y a su final extinción por el papado en 1773 (fig. I4).

Para continuar con la tradición jesuita de la que fueron herederos, los oratorianos de san Felipe Neri se volvieron grandes promotores del patrocinio de san José, sobre todo desde que recibieron el templo de la Profesa de la capital, abandonado a raíz de la expulsión en 1767 . En ese año está fechado, por ejemplo, un lienzo de José de Alcíbar donde el patrono de la Nueva España se representa junto con san Felipe Neri, el fundador de la congregación, y la Virgen de las Nieves, su patrona. ${ }^{43}$ En 1774 , el mismo pintor realizó otro lienzo donde los representados bajo el manto son el arzobispo Antonio Núńez de Haro, el virrey Antonio María Bucareli (quien les cedió el templo de la Compañía en 177I) y otros cuatro personajes benefactores de la congregación. ${ }^{44}$

Como sucedió con otras devociones jesuitas (el Sagrado Corazón, la Virgen de la Luz, Nuestra Señora del Refugio, la Virgen de Loreto o san Juan Nepomuceno), el venerado patriarca san José se convirtió en otro mudo reproche por la injusta expulsión decretada por Carlos III y se volvió un tema politizado que impugnaba visualmente las nefastas reformas borbónicas que estaban afectando a muchos de sus vasallos americanos, criollos, mestizos e indígenas. ${ }^{45}$ ¿No sería aventurado pues suponer que la proliferación de este modelo dirigido a promover la sujeción y la obediencia a la monarquía tuviera un efecto contrario en los receptores? ¿No despertaría en ellos un vago sentimiento de orgullo patrio el ver a reyes, papas, virreyes, gobernadores y obispos arrodillados ante un coronado san José, el verdadero monarca de la Nueva España?

42. Mues, El pintor novohispano José de Ibarra, vol. I, 2IO-2II.

43. Con una factura muy similar, José de Alcíbar pintó otro patrocinio de san José fechado en 1783 que se encuentra en la actualidad en el museo del excolegio de Propaganda Fide de Guadalupe en Zacatecas.

44. Corvera, "El patrocinio. Interpretaciones sobre una manifestación artística novohispana”, II8 y I38.

45. Antonio Rubial García, "La politización de las imágenes. La propaganda projesuítica antes y después de la expulsión (I750-1800)", en Memorias de la Academia Mexicana de la Historia, t. LVI (Ciudad de México: Academia Mexicana de la Historia/Secretaría de Educación Pública, 2015), 9-32. 


\section{DOI: https://doi.org/10.22201/iie.18703062e.2021.119.2760}

208

ANTONIO RUBIAL GARCÍA

\section{Epilogo}

En el Siglo de las Luces, el modelo iconográfico del patrocinio se convirtió sin duda en una importante manera de representación social en la Nueva España, inmersa en las concepciones teológicas, jerárquicas, eclesiásticas y estamentales del Antiguo Régimen. Además de los numerosos ejemplos donde el manto manifestaba simbólicamente la protección celestial, muchos otros lienzos, esculturas y relieves que no presentaban dicho elemento tenían, sin embargo, el mismo sentido de protección/sumisión y daban forma a intereses sociales con un claro énfasis en declarar la superioridad de las corporaciones eclesiásticas protegidas por el cielo. Todas esas imágenes constituían la manifestación gráfica de un modelo social, pero eran sólo una mínima parte de otras muchas maneras de representación que se insertaban en prácticas corporativas o en la participación de las autoridades e instituciones en las procesiones $\mathrm{y}$ en las fiestas.

En los virreinatos americanos esta representatividad se hacía más necesaria pues los embates de la secularización y del regalismo se manifestaban más brutales, por su situación de dependencia y por la ceguera de quienes tomaban las decisiones en Europa quienes consideraban a América sólo como una fuente inagotable de riqueza, sin tener en cuenta los perjuicios que sus políticas ocasionaban. Entre los más afectados estaban los sectores eclesiásticos, uno de los estamentos privilegiados de esa sociedad, cuya respuesta a los retos del mundo moderno fue, entre otras, mostrarse protegidos por el cielo. Las contradicciones surgidas de la confrontación de valores generaban discursos idealizados y, mientras el sistema corporativo estaba en crisis y se cuestionaba a la autoridad, ambos eran presentados dentro de un espacio inmutable y celestial, donde Dios seguía siendo un rey y un padre, los santos, unos patronos y los fieles, unos vasallos, clientes ejemplares e hijos obedientes. Ante una realidad cambiante que se desestructuraba, la única salida, el punto de fuga, era mirar al cielo con una desmesurada esperanza de que de allá llegara la solución... y la salvación. ¿ᄒ

N.B. Agradezco a Paula Mues Orts y a Jessica Ramírez Méndez por la lectura, comentarios y aportaciones a este texto y a Jorge Merlo por sus sugerencias de lecturas en el tema de san José. Una versión muy resumida de él se presentó en el coloquio A la luz de Roma. Santos y Santidad en el Barroco Iberoamericano, del 17 al 20 de septiembre de 20I8. Dicho texto fue parte de la conferencia magistral inaugural: "La santidad politizada. La utilización de los santos en la construcción de las identidades del clero regular novohispano en el siglo XviII". 